\title{
Palabras de tabaco, ambil, mambe y poporo: dones y conflictos
}

\section{La ambivalencia del intercambio: acuerdos y enfrentamientos}

$\mathrm{n}$ los dos capítulos anteriores he venido argumentando que los
muiscas interpretan su "despertar" como un intercambio de herramientas sagradas y medicinales que comenzó siglos atrás entre los chontales muiscas y los pueblos nativos de la selva amazónica y de la Sierra Nevada de Santa Marta. La devolución de estas herramientas por parte de quienes las guardaban también está relacionada con narrativas proféticas como la transmitida a través de la danza del cóndor y el águila, manifestación en la que ambas aves bailan en señal de unión y hermandad, pero un día en lugar de danzar se matan entre sí; escena que representa la desestructuración de este y otros pueblos nativos americanos por causa de la tragedia, la tristeza, las disputas, las enfermedades y otras consecuencias que dejaron los procesos de conquista y colonización. Tales consecuencias, según la misma narrativa, deben ser vividas y superadas para que nuevamente el cóndor y el águila dancen, y así despierten la solidaridad, la colaboración y la unión del pensamiento muisca. Los momentos de danza y muerte de esta manera señalan las facetas de hermandad y conflicto que caracterizan la ambivalencia del "despertar muisca". Ambas facetas fueron reveladas en el capítulo anterior cuando esbocé una cartografía de la dimensión espiritual muisca a partir de múltiples itinerarios y anclajes que poco a poco fueron configurando grupos y redes de recuperación 
cultural y de iniciados en prácticas medicinales, cuyos campos de poder simbólico a su vez establecieron linajes, alianzas y jerarquías. Con todo esto podemos percatarnos de que la visión romántica y positiva del intercambio de dones contrasta con la dimensión conflictiva determinada por enfrentamientos y oposiciones, en otras palabras, que la curación, solidaridad, enfermedad, violencia simbólica y la exclusión se manifiestan simultáneamente.

Así pues, el intercambio como práctica no siempre conlleva un acuerdo; también provoca o reconfigura conflictos que vivifican aún más estas redes de transacciones. Para el caso muisca, las transacciones corresponden a las iniciaciones en el uso de plantas medicinales, que autoridades espirituales de otros pueblos indígenas brindaron a miembros de diferentes comunidades muiscas —oficiales y no-, y que fueron complementadas o replicadas por parte de líderes muiscas que habían transitado por prácticas indígenas foráneas en sus viajes y gracias a sus relaciones personales con chamanes y taitas. Marcel Mauss (1971/1929), en su famoso ensayo sobre el don, afirmó que las personas que están involucradas en la red de contratos y devoluciones son personas morales que se enfrentan y se oponen; a esto propuso llamarlo un "sistema de prestaciones totales" (p. 4). El don trae la obligación de dar, recibir y devolver, lo cual, para Mauss, es el principio ordenador de los sistemas económicos, jurídicos y morales que estructuran lo social a la vez que regulan la convivencia y los conflictos. Ahora, considerando el estudio que aquí desarrollo, se afirma que el don también impone la obligación de que su circulación se dé de la forma correcta y armónica que su orden ético propone, de lo contrario acarrearía la enfermedad y la violencia. Por todo lo anterior y dado que las transacciones y los intercambios son la base estructurante de las redes y asociaciones étnicas aquí estudiadas, este capítulo propone abordar y analizar la manera como estas se reconfiguran a partir de sus conflictos.

Con el fin de comprender la manera en que los participantes se involucran, interpretan, perciben y actúan en sus redes, desarrollaré lo que he denominado "principio histórico-transaccional" y "principio de anclaje". Ambos principios corresponden a fórmulas discursivas que configuran relaciones legítimas con el pasado y que permiten establecer 
coherencias con el presente mientras se despliegan y operan esquemas de percepción, pensamiento y acción que hacen del campo etnopolítico muisca un "espacio social de poderes simbólicos", si tomamos los conceptos de Bourdieu (1989). Los conflictos se manifiestan en acciones que demuestran que las diferentes facciones no coinciden en sus interpretaciones sobre lo que debe ser el "despertar muisca" y la obligación que ello trae para sus dolientes. Cuando el conflicto escala y llega a niveles inconmensurables, se producen los "conflictos morales" (Pearce y Littlejohn, 1997). El modo en que se da esta escalada y la aplicación de los dos principios propuestos conforman nuestro modelo analítico de los conflictos etnopolíticos. Con ello reitero la premisa de comprender la etnicidad muisca como heterodoxa. Entonces, abordar la ambivalencia de las redes de intercambios que constituyen el campo etnopolítico muisca nos obliga a entender cómo se dan los conflictos, cómo se agencian, cómo se transforman, cómo se solucionan y cómo se renuevan.

\section{Principios "histórico-transaccional” y "de anclaje"}

En el año 2006, comencé mi trabajo etnográfico en torno al tema muisca y su recomposición cultural y política. En ese entonces me preguntaba por la manera en que una organización autodenominada PNMC creaba escenarios y repertorios mediante los cuales buscaba rescatar la ritualidad y la religiosidad muiscas bajo el liderazgo de autoridades cuya identidad étnica muisca se definía desde dos particularidades: por un lado, netamente desde el autorreconocimiento, es decir, sin haber transitado la ritualidad jurídica con la cual el Estado colombiano sustenta la pertenencia étnica oficial. Por otro, desde una construcción discursiva de identidad, es decir, dichos líderes se llaman a sí mismos chyquys, título asignado a autoridades espirituales de alto rango y gran poder medicinal (Gómez Montañez, 2009). Tales particularidades son actualmente uno de los motivos centrales que han confrontado la manera como los cinco cabildos indígenas muiscas reconocidos por el Ministerio del Interior comenzaron a crear un campo etnopolítico.

Al tener en cuenta la dimensión histórica de estas confrontaciones, dos evidencias emergen del análisis. La primera es, siguiendo a Johan 
Galtung (s. f.), que lo que parece ser el objeto de una disputa en el presente resulta ser la consecuencia de un motivo muy antiguo, lo cual transforma el mapa original del conflicto. Así mismo, Pearce y Littlejohn afirman que todo conflicto de orden moral se torna "intratable" en la medida en que sus causas originales se vuelven irrelevantes y las nuevas causas del conflicto se generan por las acciones que permanecen dentro del mismo conflicto (1997, p. 68). Bajo mi mirada, el paso del tiempo devela que tras una transacción negativa entre las dos primeras partes que intervienen en un conflicto subyacen transacciones e intercambios de diversas índoles entre los miembros de lado y lado. Podemos decir entonces que la historia de un conflicto la configura una serie de encuentros y desencuentros, consensos y desacuerdos, además la continua aparición y disolución de facciones radicales y flexibles en cada parte con relación al conflicto y, por consiguiente, alianzas y transacciones que generan vínculos y escenarios relacionales de diferente orden. Todo esto es lo que denomino "principio histórico-transaccional" del conflicto: subyacente al escenario más evidente de encuentro de las partes, otras transacciones operan y atraviesan las fronteras que dicho escenario original ha marcado y que se transforman con el devenir.

Lo segundo que se evidencia es la diversidad de formas como cada parte del conflicto legitima su participación en las arenas de lucha en el presente con base en las narrativas que construyen el pasado de dicho conflicto. Algunas narrativas son construcciones de tiempos remotos —ejemplo la danza del cóndor y el águila- y otras corresponden a relatos y explicaciones de sucesos recientes, atravesados por los conflictos y las complejidades inherentes a los intercambios y préstamos de la red étnica muisca. De esta manera, la memoria deviene uno de los campos que componen los "imaginarios de la violencia”, ya que se emplea para producir maneras de relatar lo acontecido, y así poder definir y acentuar la identidad y la posición de cada parte (Schmidt, 2001). En la puesta en práctica de dicha operación, cada integrante de la red conflictiva aplica una serie de mecanismos discursivos que le permiten asumir el papel de doliente de dicho pasado o, por lo menos, integrar su historia personal en la narrativa que se ha construido colectivamente. La persona se integra al relato conflictivo, asumiendo 
papeles, estableciendo cadenas de solidaridades y lealtades, definiendo su posición respecto a cada disputa y legitimando su derecho a ser integrante de la red étnica, esto mediante anclajes que la conectan moral y coherentemente con los pasados más próximos y los muy lejanos. A esto lo llamo "principio de anclaje" de los conflictos étnicos: se elaboran memorias a partir de la manera como algunos de los integrantes de la red se narran a sí mismos y se vinculan moralmente al tejido conflictivo de intercambios y transacciones, y así, simultáneamente, legitiman su identidad étnica muisca.

\section{Mapas y escalas de la inconmensurabilidad: el lado venenoso del don}

Si seguimos los argumentos de Mauss (1971/1929), el don —según su raíz germánica gift- es tanto "regalo" como "veneno". Es un honor recibirlo, pero es peligroso por cuanto su compromiso de devolución es sagrado y compromete fuerzas y energías que podrían causar daño si se incumplen los contratos. En palabras de Mauss, esto "constituye el trasfondo sobre el que se ha creado la moral del don-cambio" (p. 33). No es un intercambio libre y desinteresado, sino que siempre busca mantener relaciones de beneficio y alianzas. Las redes de abuelos e iniciados a las que me referí en el capítulo anterior se fundamentan en los dones devueltos a los muiscas por otros pueblos indígenas. Los anclajes y linajes que estas iniciaciones producen son factores de conflictos porque crean cadenas de solidaridades y rivalidades. Y aunque las características del don nos remiten en principio a operaciones energéticas ligadas a la dimensión espiritual, las fuerzas desplegadas tienen implicaciones y se reproducen en escenarios de la dimensión política de la etnicidad muisca. Una persona que sea juzgada moralmente en el plano de las prácticas medicinales, por ejemplo, puede ser excluida de espacios de participación indígenas en el marco de proyectos institucionales. De igual forma, los conflictos y juzgamientos en los planos político y administrativo pueden ser explicados como un desequilibrio en el orden espiritual. Además, la lucha por la representatividad y legitimidad de algunos líderes de diferentes facciones como autoridades espirituales muchas veces corresponde con la lucha por 
su representatividad y legitimidad como autoridades indígenas ante el Estado colombiano y la sociedad en general. Así, las dimensiones espirituales y políticas se alimentan mutuamente.

En capítulos anteriores argumenté que la emergencia de un campo espiritual muisca reconfiguró el proyecto etnopolítico al aportar estéticas, narrativas y redes sociales cohesionadas mediante la canalización de emociones que conllevan las iniciaciones. Pero el campo espiritual también aporta modelos morales y cosmológicos que explican y sustentan las acciones políticas en el presente, es decir, el escenario donde se ponen en práctica los poderes simbólicos. En el siguiente testimonio de Henry Neuta, líder de la comunidad muisca de Bosa, encontramos una versión resumida de la narrativa sobre el intercambio y la devolución de dones entre el pueblo muisca y otros pueblos, así como los principios y las obligaciones que esta versión propone, en la que el muisca es el centro de una gran red de intercambios que no solo tiene su origen en las transacciones comerciales del pasado precolombino, sino que se sustenta en otros planos energéticos y morales. Por supuesto, esta versión refuerza la relación entre la desarmonía y la colonización y desafía la producción de verdad histórica:

Como todo debe vivir en armonización, los pueblos han entendido que hoy por hoy hay una desarmonía, un desequilibrio, por eso mismo la misma humanidad ha generado acciones en pro de la naturaleza, pero el orden no será si no nace del saber, del entender de cada persona. Y para ello, que haya equilibrio, toca haber un entendimiento desde los pueblos. Desde lo muisca sería su trabajo de articulación con los demás pueblos, con los que históricamente comercializaba la sal, comercializaba las esmeraldas para pagamentos y en eso, hasta cierto punto, se puede hacer. Cuando el proceso de la colonización rompe ese ejercicio, rompe alguna manera esa conexión histórica entre los pueblos. Sin embargo, el pensamiento del pueblo muisca queda guardado para protegerse hasta que llegara el momento que podamos decir que ha nacido ese momento de que el pueblo muisca vuelva a reclamar lo que es suyo, sus usos y costumbres, su lengua, su tradición que están guardadas y protegidas en algunos pueblos. Para que llegado 
el momento lo entregara, pero ese entregar no es como entregar un libro, es entregar desde el pensamiento y la tradición. ¿Cómo se hace para entregar esa tradición y ese pensamiento? Pues creando los círculos de palabra, los rituales, las ceremonias, y en eso es como el Internet, el wifi, esa línea que no se ve, pero que espiritualmente es una conexión que nos permite hoy por hoy a los que tenemos la tradición, el linaje, recoger todo eso para generar el orden. Entonces hablan de un nuevo orden. Un nuevo orden qué es, pues que los pueblos, la humanidad, entre en consenso. (Henry Neuta, 24 de agosto del 2012)

En la medida en que dones como la medicina, la lengua o las costumbres sean devueltos, sus fuerzas y energías circularán armónicamente, si no, vendrá la enfermedad, el conflicto y demás estructuras caóticas. Fieles a estos modelos, algunos líderes muiscas consideran que la emergencia de la espiritualidad y el fortalecimiento cultural conllevan las complejidades de la "limpieza" y el "orden".

La suciedad y el desorden son tropos mediante los cuales los muiscas interpretan los conflictos que deben ser superados para hacer posible el "despertar". Al igual que los otros tropos analizados anteriormente, estos atraviesan fases críticas cuya superación significa el paso del caos al orden. Los muiscas expresan que las acciones producidas por los abuelos espirituales - tanto los del territorio como las plantas medicinales - pueden hacer las veces de fuerzas que "sacuden" y hacen brotar "el negativo". Aunque los practicantes de la nueva medicina muisca procuran separar y diferenciar su campo del catolicismo - por ejemplo, con el uso de la palabra espiritualidad en lugar de religión o religiosidad_, el modelo moral cristiano parece resurgir mediante la oposición binaria lo bueno/lo malo.

Es que ahí está, ahí está. Es que ese ego viene de la parte espiritual porque están los dos: está el espíritu negativo y el espíritu positivo. Entonces como ha venido mandando durante harto tiempo el espíritu negativo, y con lo del empoderamiento espiritual, quien va despertando con un espíritu positivo, sin ambicia [ambición], sin envidia, sin codicia, sin egos de ninguna clase, entonces el negativo 
no quiere, él quiere bailar y apoderarse y ponerle barreras al positivo para que él no pase, entonces ahí está el problema, ahí es donde está la situación, no hay nada más que hacer. En los pueblos muisca tenemos que fortalecer es el positivo. Si usted sabe, bien, tranquilo, hágale, sígalo por ahí, siga su camino. Hombre, si necesita algo y ve que yo le puedo ayudar, venga o llámeme, pero no lo estamos haciendo. (Fernando Castillo, 13 de abril del 2012)

Es importante sanar eso, y en esa parte es donde hay que trabajar, hay que intensificar ese trabajo. Pero, ¿qué se da en ese trabajo? No está acomodado lo que se tiene que acomodar. Y como sucede con la Madre Tierra, tienen que haber muchos acomodamientos, muchos temblores, muchas cosas se tienen que mover. (Jimmy Fiquitiva, 15 de junio del 2012)

Cuando empezó esto, como lo entendemos hoy día, había un negativo como se habla de la tradición, y el mismo negativo dijo: “Acá se están despertando". Y entonces se sacudió, y empezó a generar conflictos al interior de la comunidad entre familias. (Henry Neuta, 24 de agosto del 2012)

La llegada de las herramientas espirituales devueltas por otros pueblos indígenas a los muiscas conlleva las fuerzas energéticas de los dones. Es por esto que en los tres testimonios anteriores se destaca que el "despertar muisca” implica la activación de las fuerzas de los dones que se han devuelto y que se están recuperando como parte de la cultura. Fiel a un modelo medicinal y terapéutico, estos dones producen crisis para que luego venga la curación, el orden y la armonía. Pero hay un aspecto del intercambio y la entrega de dones estudiados por Marcel Mauss (1971/1929) que en nuestro caso ayuda a explicar cómo los integrantes de la red espiritual muisca interpretan los factores de los conflictos del "despertar". El autor explora la manera en que algunas sociedades primitivas hacen cambios y contratos aparentemente voluntarios bajo la forma de regalos, pero que en realidad presuponen su devolución obligatoria. Se pregunta por la fuerza que tiene la cosa que 
se da, que obliga a ser devuelta. El potlach ${ }^{65}$ y el kula ${ }^{66}$ son los casos etnológicos de los estudios del don y sus implicaciones conflictivas por antonomasia. En ambos se aplica la obligación de devolver el don para evitar la guerra y la violencia. La relación entre la devolución del don y el conflicto entre el pueblo muisca y otros pueblos cumple una condición fundamental que, por ejemplo, también se da entre los maoríes de Nueva Zelanda estudiados por Mauss. Los maoríes intercambian regalos (taonga) que llevan consigo un espíritu llamado "hau". Para comprenderlo, sirva esta ilustración: si a una tercera persona le doy algo (taonga) que recibí de mi amigo, y a modo de pago esa persona me regala algo, este taonga que ahora recibo conlleva el hau del taonga de mi amigo. Por lo tanto, debo devolverle a él el taonga que he recibido; no puedo quedarme con este taonga aunque lo quisiera, de lo contrario su hau podría causarme enfermedad, desgracia, incluso, la muerte. Más allá del intercambio económico o informal, esta cadena es soportada por un intercambio energético de fuerzas espirituales que mantienen la cohesión de la red mediante los actos de dar, recibir y devolver. Es como si el hau tuviera vida y siempre quisiera retornar a su lugar de origen. En otras palabras: “Dentro de ese sistema de ideas,

65 En Alaska, la palabra potlach significa 'alimentar' y 'consumir'. Bajo el principio de rivalidad y antagonismo entre tribus, consiste en una invitación en la que el anfitrión destruye sus riquezas para imponer su jerarquía y estatus ante el jefe invitado, que a la larga también es un asociado en esta red. A esta modalidad Mauss prefiere denominarla "prestaciones totales de tipo agonístico" (1971, p. 4). En este sistema, tanto negarse a dar como olvidarse de invitar o negarse a aceptar equivale a declarar la guerra, pues es negar la alianza y la comunión. A la propiedad se le otorga, de esta manera, un lazo espiritual que, a su vez, reproduce un régimen social (p. 6).

66 Es una gran red que se extiende por todas las islas Trobiand, en la que los jefes se intercambian gimwali. La tribu que recibe el don debe devolverlo con posterioridad y con usura. Los objetos de cambio son vaygu'a, una especie de monedas. Hay de dos tipos: mwali o brazaletes, que se transmiten de Oeste a Este. "Es propiedad y posesión, es regalo y cosa alquilada, es cosa vendida y comprada, al mismo tiempo que es cosa depositada, sujeta a mandato y a fideicomiso, ya que se entrega con la única condición de que sea usada por otro o de transmitirla a un tercer 'compañero lejano', murimuri" (Mauss, 1971, p. 11). También están los soulava o collares que viajan y se transmiten de Este a Oeste. 
hay que dar a otro lo que en realidad es parte de su naturaleza y sustancia, ya que aceptar algo de alguien significa aceptar algo de su esencia espiritual, de su alma" (Mauss, 1971/1929, p. 6).

Cuando un abuelo o mayor, sea mamo, taita, chyquy o cualquier autoridad espiritual, entrega un don o inicia a alguien en el uso de una planta sagrada — que lleva consigo un mito de origen- está entregando la fuerza de su linaje espiritual y su palabra de medicina. Si esa palabra no se cuida ni se devuelve, el abuelo y el discípulo se pueden enfermar. Por esa razón, en la medida en que se crean cadenas de entrega de dones e iniciaciones, sus integrantes procuran proteger el linaje espiritual del abuelo dador, construyendo así órdenes morales para identificar posibles amenazas internas o externas. De igual forma, si un iniciado entrega su don a otro, debe hacerlo siguiendo las reglas del abuelo mayor, de lo contrario, podría estar entregando irresponsablemente un poder que provoca desarmonía y enfermedad.

En los apartados siguientes notaremos que un argumento recurrente para explicar los conflictos y leer moralmente al otro surge de la pregunta por su grado de responsabilidad en la recepción y entrega de dones devueltos por los abuelos indígenas mayores. Cuando estos abuelos se enferman y los espacios medicinales colapsan, la desarmonía se trata de explicar buscando culpables. De esta manera se establecen lealtades, se afianzan colaboraciones y se forjan disputas por la ocupación de papeles y posiciones en el tejido conflictivo. En este punto, el trabajo de campo, mediante la observación participante en escenarios de palabra y curación muiscas y la recopilación de varios testimonios, permite rastrear todo esto a partir de la aplicación de los principios histórico-transaccional y de anclaje. A su vez, en las disputas, especialmente, se pueden identificar las escalas de los conflictos, que van desde niveles elementales de diferencia hasta situaciones inconmensurables.

Las redes de información, intercambio, trabajo espiritual, transacciones y de anclajes configuran diferentes mapas de conflicto moral, los cuales trazan y definen rutas e itinerarios de lo que Pearce y Littlejohn denominan el "paso de la diferencia a la confrontación" (1997, pp. 67-68). En el presente estudio se entiende que de la identificación de características diferenciales entre las organizaciones, grupos y redes muiscas es posible pasar a escenarios en los que se busca 
tanto la colaboración y la inclusión como la exclusión y la capitulación de la alteridad ${ }^{67}$. Ambos autores parten de la noción conflicto cultural propuesta por el James Davinson Hunter, que hace referencia a las hostilidades enraizadas en diferentes sistemas de entendimiento moral. La finalidad de tales hostilidades es la dominación de un ethos cultural y moral sobre todos los demás (Hunter, citado por Pearce y Littlejohn, 1997, p. 49). De esta manera, el "conflicto moral" aparece cuando las personas profundamente inmersas en mundos sociales inconmensurables chocan. Su intensidad se alimenta cuando las acciones de un lado son tratadas como maliciosas o estúpidas por el otro. Para ello, cada participante aplica su orden moral con el fin de comprender su experiencia y hacer juicios acerca de acciones apropiadas e inapropiadas (p. 51). Este tipo de modelos de análisis suelen buscar comparativamente las diferencias de orden moral entre etnias o grupos culturales disímiles que llegan al "estado de guerra étnico" (ethnopolitical warfare) (Chirot y Seligman, 2002).

Volviendo ahora a mi estudio, propongo demostrar que estos choques de ethos morales también se presentan dentro de las etnias que, como la muisca, conforman campos etnopolíticos en los que, a medida que se reconstruye un cuerpo común de valores e ideales que sustentan la identidad étnica y la organización colectiva, sus miembros o seguidores luchan por tener una posición más o menos privilegiada que les permita legitimar su representatividad y autoridad y ejercer poder. La heterodoxia del campo etnopolítico muisca demuestra entonces que no siempre las fronteras de los órdenes morales corresponden a las de las identidades étnicas y que, por el contrario, estas identidades, por cuanto son cambiantes, dinámicas y situacionales, pueden establecer diferentes maneras de construir y consolidar un cuerpo de valores y reglas. En otras palabras, en la medida en que se configuran redes de solidaridades y alianzas dentro de la etnia muisca se construyen

67 La elección entre la colaboración o la competencia es analizada por Pearce y Littlejohn (1997, pp. 35-36) a partir de los "patrones" o "gramáticas" que siguen quienes participan en un conflicto, basándose en la teoría de juegos. Tales gramáticas son la base del análisis de los conflictos estudiados en este capítulo. 
diferentes ethos. Comprendamos rápidamente cuál es el modelo de Pearce y Littlejohn para analizar la escala moral de los conflictos.

Primeramente, según estos dos investigadores, el primer nivel inconmensurable se da en la medida en que "los participantes usan el mismo vocabulario pero para significar cosas diferentes" o "en el uso de diferentes vocabularios para funciones comparables" (1997, p. 68). El trabajo de campo, al registrar y definir un mercado del lenguaje sobre la etnicidad muisca, también ha logrado identificar diferencias en los planos discursivo y retórico. Las diferentes maneras de entender e incorporar lo que significa ser muisca, chyquy, abuelo, autoridad, así como el valor y uso de elementos rituales y costumbres, pueden configurar disputas en las que se tratan de establecer e imponer versiones y validar jerarquías simbólicas. Otorgarle un significado u otro a un lugar o cualquier elemento que forme parte de la recomposición cultural étnica, por ejemplo, no solo marca diferencias semánticas, también crea cadenas de lealtad, linajes y funciones. No es lo mismo determinar significados, siguiendo la palabra de un mamo serrano que la de un taita amazónico, pues implica, por ejemplo, darle más validez a una planta sagrada que a otras. Tampoco es lo mismo considerar antiguo y contenedor de gran sabiduría al pueblo muisca que creerlo todavía inexperto y carente de la guía esencial de sus propios mayores en su “despertar”. Asimismo, otorgarse u otorgarle a alguien la autoría de una frase o definición que comienza a circular y a ser retransmitida en el mercado del lenguaje muisca establece autoridades con mayor o menor representatividad en el campo etnopolítico, las cuales se legitiman o deslegitiman de acuerdo a quienes deciden o no formar parte de su séquito.

En un segundo nivel de inconmensurabilidad, "cada participante se describe a sí mismo en oposición con cada uno" (Pearce y Littlejohn, 1997, p. 68). Así se definen membresías a facciones particulares y, en otros casos, nuevas facciones se forman de acuerdo con las fragmentaciones ocurridas por tales percepciones constantes de diferencias. A su vez, las "acciones que un lado piensa como las que calmarán la situación o solucionarán el conflicto son percibidas por los del otro lado como una muestra de perfidia del primero" (Pearce y Littlejohn, 1997, p. 68), esto los obliga a responder con la continuidad o la intensificación 
del conflicto. Ambas situaciones de este nivel hacen del conflicto un campo dinámico y le añaden nuevas causas que lo renuevan y mantienen. Durante mi tiempo de trabajo, casi siete años, las comunidades se transformaron radicalmente; las comunidades oficiales se fraccionaron y establecieron fronteras entre quienes participan en la red étnica desde los planos político y administrativo de los cabildos e instituciones y quienes militan en el campo de lo medicinal y espiritual. Personas que en un momento histórico de estas organizaciones asumieron el papel de médicos y líderes rituales, como los registrados por Martínez (2009), en Bosa, fueron desconocidas y desplazadas por personas iniciadas por diferentes abuelos y que entregaron diferentes medicinas. Líderes que en el capítulo anterior caractericé como itinerantes, sin comunidad fija, que transitaron por varios grupos y siempre justificaron sus desplazamientos a medida que surgían diferencias y entraban en disputa con miembros de algún grupo. Así mismo, fue normal en mi trabajo de campo detectar que líderes que en un momento estaban aliados y formaban una misma facción luego se separaban y lideraban nuevas facciones con un alto nivel de competitividad y disputa entre sí. Pero tal como lo expliqué páginas atrás cuando me referí al principio histórico-transaccional del conflicto, mientras los líderes chocaban, otros miembros de las mismas facciones no mantenían relaciones problemáticas; podían incluso apoyarse mutuamente y aliarse.

Finalmente, el modelo de Pearce y Littlejohn indica que los "participantes son incapaces de articular la lógica del mundo social del otro lado de forma que tal lado lo acepte" (1997, p. 68). Como es habitual en los escenarios de pugna política, ninguna parte siente que sea bien conocida e interpretada por su oponente. Además, "el discurso entre los grupos en conflicto contiene una gran cantidad de afirmaciones sobre lo que anda mal del otro grupo" (p. 68). Al hallarme frente a un panorama de alta inconmensurabilidad entre participantes muiscas de estas redes transaccionales y conflictivas, mi problema de investigación doctoral se hizo evidente en esta etapa. Al decir de Pearce y Littlejohn respecto a su último paso a la inconmensurabilidad, "si se pregunta o invita a imaginar una solución del conflicto, los participantes solo pueden pensar en la capitulación y eliminación del otro grupo" (p. 68). Estas eliminaciones se presentaron de varias maneras; 
unas veces fueron materializadas, excluyendo directamente a algún líder o grupo de espacios donde las comunidades indígenas participaban en debates y consultas con instituciones estatales sobre políticas que las afectaban; otras veces pasaron desapercibidos en importantes fiestas y celebraciones; algunas veces unos grupos buscaron que otro fuera deslegitimado estatalmente y ante la sociedad mayoritaria, y en otras ocasiones, los intentos de capitulación se presentaron a manera de guerras y batallas en el campo mágico y espiritual, es decir, algunos líderes que manejan medicinas y métodos chamánicos de poder se enfrentaron entre sí. Pero en este último caso, el intento de eliminación del otro implicó siempre la aceptación de su condición de indígena y abuelo poderoso aunque fuese ambicioso y corrupto. Esto me llevó a concluir que los criterios de exclusión no siempre coincidieron con los de pertenencia étnica muisca, sino que trascendían a criterios de orden moral que la misma red étnica iba elaborando en medio de sus fragmentaciones y asociaciones.

Los casos que expondré en este capítulo atraviesan en cierta manera las fases de la escalada del conflicto moral propuesta por ambos autores, aunque no siempre se presentan secuencialmente y del mismo modo. Además, la transformación de los conflictos a veces conducía a momentos de aparente distensión y colaboración para volver a escalar hacia la inconmensurabilidad. Esta última se presenta en la medida en que también las narrativas, anclajes y fórmulas discursivas del mercado del lenguaje de la etnicidad muisca construyen un cuerpo de valores y principios morales para conectarse con el pasado y validar las acciones de quienes deciden formar parte de la red étnica. Con base en lo anterior, mi tesis es que en el sistema de transacciones de la red étnica no solo se generan relaciones colaborativas y armoniosas, sino también conflictivas en varios niveles, pero estas últimas, con sus dinámicas opositoras, terminan configurando otro tejido que sustenta y afirma la existencia de un proyecto etnopolítico colectivo. Lo anterior se podría definir como la dimensión política del "despertar muisca”. Los procesos de competencia y violencia que expondré a continuación, lejos de excluir al oponente, lo integran en la medida en que precisamente el oponente es leído y detectado como un aportador energético en el sistema de intercambios. Quiere decir que debemos 
superar la mirada que desintegra lo étnico-colectivo cuando hay exclusión, y ubicarlo en una red más amplia de relaciones. Bajo esta óptica, las oposiciones entre líderes indígenas, pese a que fragmentan lo colectivo, entendiéndolo como grupos estables y armoniosos, reafirman la existencia de una red más compleja desde la que se teje el proyecto de resignificación de lo muisca.

Dicho lo anterior, propongo analizar los conflictos del campo etnopolítico muisca mediante el trazado de "mapas de la inconmensurabilidad", como he propuesto llamar a los desarrollos narrativos y argumentales de los conflictos de la red étnica muisca presentados desde la etnografía, que contienen los siguientes componentes: 1) líderes y miembros de comunidades y grupos que por medio de sus itinerarios y anclajes se vinculan a la red conflictiva y legitiman su participación en el proyecto del "despertar muisca"; 2) conflictos que tienen sus propios itinerarios a través de los cuales las causas originales se desdibujan, emergiendo así otras nuevas para que los conflictos, entonces, se vuelvan intratables y estructurantes de la red étnica; 3) narrativas, explicaciones y discursos que retroalimentan el mercado del lenguaje muisca y que exponen principios y órdenes morales a partir de los cuales se juzgan y legitiman las acciones propias y ajenas; 4) la configuración de campos de poderes simbólicos en los cuales los miembros de la red entran en disputas mientras construyen renovadas e imaginadas formas indígenas para llevar a cabo los conflictos, agenciarlos y solucionarlos; 5) el papel de algunas autoridades de otros grupos indígenas, algunas veces como mediadores y otras como causantes del conflicto, al liderar redes, linajes, iniciaciones y cadenas de alianzas y seguidores que a su vez configuran nuevos ethos y, por ende, diferencias y confrontaciones, y 6) la emergencia y el desarrollo de métodos de resolución de conflictos coherentes con los principios curativos del campo espiritual muisca que también devienen espacios sociales de poderes simbólicos y de reproducción de conflictos.

Debido a la gran complejidad que representa trazar el sinnúmero de causas y tipos de conflictos en la amplia red étnica muisca en relación con la circulación de dones, he decidido definir dos nodos principales de dicha red que corresponden a su vez a escenarios donde los conflictos emergen, se discuten, se negocian y se transforman. Esto también 
permite agrupar en dos núcleos narrativos los relatos y las argumentaciones. El primer nodo es la maloca del Jardín Botánico de Bogotá, la cual se constituyó en el legado del taita Víctor Martínez Taicoma, indígena murui del Amazonas, a los muiscas en función de su "despertar". Esta maloca, a causa de los conflictos que la atravesaron, fue considerada "enferma" al igual que su constructor y terminó siendo demolida para evitar que lo que inicialmente fue un motivo de unión y colaboración entre pueblos indígenas se convirtiera en generador de “más desorden". El segundo nodo es el Templo del Sol de Sogamoso, donde en medio de los intentos de renovación de la Fiesta del Huan o Zocam y para que fuera liderada por los muiscas confluyeron conflictos en torno a la representatividad de sus líderes, la institucionalidad del saber sobre la cultura muisca y el papel de autoridades espirituales foráneas en el “despertar”. Respecto a este último punto, a los dones entregados por el taita Víctor Martínez Taicoma se les sumarán aquellos entregados por taitas yageceros y mamos poporeros. Resta decir que a medida que desarrolle cada núcleo narrativo se integrarán actores, prácticas y otros escenarios ceremoniales y políticos donde se disputan la identidad y la representación indígenas muiscas. Por consiguiente, se entenderá que ambos son escenarios tanto de disputa como de negociación. Aunque en algunos momentos la inclusión de tales elementos podrá parecer un punto de fuga en nuestra narrativa, la idea es mantener el vínculo de todos con cada nodo central.

\section{Auge y caída de una maloca en Bogotá}

El taita Víctor Martínez Taicoma, cacique de la comunidad murui del corregimiento La Chorrera, departamento del Amazonas, fue el constructor de la maloca del Jardín Botánico de Bogotá ${ }^{68}$. Al hacerla, la maloca contuvo la fuerza espiritual de su linaje y de su medicina. Según Sánchez (2004), en el momento de pedir permiso a los espíritus del territorio bogotano para su construcción, estos desconocieron

68 Una breve referencia a la relación del taita Víctor Martínez Taicoma y la maloca del Jardín Botánico de Bogotá la expuse en el apartado "Una maloca en Bogotá: el papel de los abuelos foráneos” del cuarto capítulo. 
a los abuelos foráneos y les produjeron "malos sueños y contrariedades" antes de la "revelación" que otorgó el permiso (p. 133). Aunque la construcción de esta maloca en 1997 siempre fue considerada como un hito para las comunidades amazónicas residentes en Bogotá, por lo que significaba para su cuidado, protección y reproducción culturales, lo cierto es que el abuelo Víctor siempre la ha explicado como fruto de un sueño en el que recibió la misión de ayudar a que el pueblo originario de la capital se despertara. El mismo abuelo expresa que "al principio no llegaron los muisca” y que él se seguía preguntando cuándo aparecerían. Cada vez que este fragmento de la historia personal del taita es narrado en un escenario específico, los miembros del grupo o la red que lo organizan suelen atribuirse el papel de receptores legítimos de los dones del taita o, por lo menos, de quienes sí comprendieron su palabra, respetaron su medicina e hicieron fluir armónicamente su fuerza sanadora para que Víctor creara cadenas de su linaje espiritual en el centro del país. En este caso se entiende que el linaje es transmitido no por vínculos de sangre, sino por vínculos entre el iniciador y su iniciado.

\section{Cadenas de entrega y recepción de dones: la palabra de los abuelos y sus ethos}

Varias fueron las expresiones que escuché en mi trabajo de campo con las que los participantes de los espacios medicinales de la maloca agradecían al taita por "enseñarles a ser muiscas de nuevo". Las plantas medicinales que el taita "entregó" fueron el tabaco (en los preparados de josca bejesca, para fumar o rapear; y de ambil, pasta o solución viscosa para chupar) y la coca (en el preparado de mambe, polvo elaborado con las hojas de coca tostadas que luego es depositado en la boca, ensalivado y digerido lentamente). Mientras que el tabaco significó en esos escenarios "el pensamiento del Padre", el mambe de coca representó "la palabra de la Madre". Según su investigación sobre los estudios de chamanismo en Colombia, James y Jiménez (2004) afirman que el uso de estas plantas por parte de las generaciones amazónicas posteriores a la época del auge de la cauchería permitió el rescate y la reproducción de la memoria de los grupos indígenas. Roberto Pineda 
Camacho, uno de los antropólogos que más ha estudiado la cultura murui, se refiere al mambe y al ambil así:

La coca se pila y tuesta [en budares, ollas de barro o canecas de metal]. El polvo cernido se mezcla con ceniza de yarumo u hoja de uva de monte. El producto se engulle [o mambea] y se disuelve paulatinamente, formando abultadas pelotas en las dos mejillas. Todo hombre posee su recipiente de coca y lo intercambia con sus interlocutores. El tabaco se consume de forma semilíquida [ambil]. Generalmente los adultos llevan, asimismo, un pequeño frasquito de ambil que circula con ocasión de las reuniones o las conversaciones. Durante una velada, los participantes "chupan” ambil depositado en una totuma o un cuenco. La lamida del ambil en comunidad refleja un sentido de unanimidad y solidaridad entre los concurrentes; por medio del ambil se invita a otras malocas o gentes para las celebraciones rituales u otros actos sociales. Su consumo, no obstante, se restringe habitualmente a los hombres adultos de un grupo doméstico. (Pineda, 1987)

En la maloca del jardín botánico, este uso del mambe y del ambil exclusivo para el hombre se transformó; las mujeres también recibieron la medicina del taita. Al mambear y chupar ambil, se creaba entonces un espacio de comunicación y curación. Sin embargo, la medicina del taita implicaba la "entrega" de una palabra que debía devolverse como señal de aprendizaje por parte de la persona iniciada y como muestra de respeto y cuidado del espíritu del abuelo dador. Janeth Yanguma, considerada la abuela mayor de PNMC en Suba, explica cómo entiende el compromiso moral de "devolver la palabra" frente al maestro y a la propia vida del discípulo que recibe los dones.

Devolver la palabra es devolver el conocimiento que yo he adquirido al momento en que yo verdaderamente haya comprendido el chupar ambil. Entonces cuando a mí me entrega ambil el anciano y me dice: "Chupe ambil", y le pregunto palabra de ambil y me dice: "Chupe ambil”, esa era la única palabra que me decía. Entonces cuando empiezo a chupar ambil empiezo a comprender que eso que me lega es el conocimiento que yo necesito, 
es mi conocimiento. Entonces cuando yo tengo mi conocimiento, y paso por ese camino, por esa suna, es cuando voy y le devuelvo la palabra al anciano y le digo yo: "Ya entendí por qué sumercé me pedía que chupara ambil”. (Janeth Yanguma, 11 de mayo del 2012)

El mambeadero de la maloca iba proponiendo su propio ethos al integrar al abuelo dador y sus discípulos en una red de entrega y devolución de palabra de ambil y mambe que, a su vez, configuraba un método de limpieza, curación y, de algún modo, de superación personal. Así, el “despertar muisca” establecía sus propios principios y órdenes éticos, además de las metodologías de enseñanza y reproducción comunitaria.

La recepción del don también significa una gran responsabilidad respecto a su posesión y circulación. No solo en la maloca se repartía el tabaco y el mambe como medicinas entre los miembros que participaban, también desde el manejo de PNMC en conjunción con las enseñanzas del taita se iba tejiendo una red de prácticas espirituales muiscas, y a medida que los participantes de la red se ratificaban líderes espirituales otros dones se iban entregando como parte de las cadenas de iniciación y curación. Uno de esos dones que acompañan permanentemente los espacios de "mambeo muisca" es la chicha. Tanto las abuelas chicheras como los abuelos mambeadores siempre expresaban que era un imperativo "cuidar" la planta sagrada o bebida que fuera entregada a alguien. Cuando le pregunté a Janeth Yanguma sobre el riesgo de que una persona discípula hiciera un mal uso de la herramienta entregada, ella me dio una respuesta en la que se advierte que la persona dadora es el puente que vinculaba al iniciado con una entidad más compleja, el cosmos, y desde la cual se "pagaban" las culpas: "Ya eso es problema de ellas y del cosmos. Porque en sí en sí, uno entrega pero el negocio no es con uno, el negocio es con el cosmos [...] y es un compromiso espiritual" (Janeth Yanguma, 11 de mayo del 2012).

A medida que personas iniciadas ingresaban a estas dinámicas de la maloca se iban vinculando a redes de lealtad, respeto y colaboración entre abuelos y discípulos. Por ejemplo, Sigifredo se convirtió en un líder muisca y un iniciador. La expresión "la palabra del abuelo Suaga Gua” y otras similares alusivas a la palabra de los iniciadores configuraban cadenas de alianza y protección en medio de las prácticas 
medicinales y terapéuticas en la maloca, que también se reproducían en otros escenarios como chunzúas o cusmuyes donde PNMC llevaba a cabo ceremonias y reuniones de su comunidad. De igual forma la palabra de uno u otro abuelo se relacionaba con el sabor del tabaco, el ambil, el mambe o la chicha que este repartiera en dichos espacios. En este punto cabe anotar que como etnógrafo, a partir del sabor logré elaborar cartografías de las redes de maestros e iniciados en este tipo de espacios medicinales ${ }^{69}$.

Avanzaba mi trabajo de campo, y el sabor del tabaco era cada vez más familiar. En cierta medida, la amargura del paladar se convirtió, en un principio, en el indicador que separaba claramente el espacio medicinal del profano cotidiano: entrar en este significaba saborear el tabaco en múltiples niveles y presentaciones (cigarro, ambil, polvo). Pero lo cierto es que el tabaco nunca sabe igual. Industrialmente, existen dos técnicas que usan las tabacaleras artesanales para armar los cigarros con el fin de saborear el tabaco; mojándolos ya sea en vino tinto, ya sea en chocolate. Ahora, en el espacio medicinal, cada "sabedor" o "persona con alto nivel de conocimiento" en lo muisca prepara sus propios tabacos, es decir, cuando las mismas personas no son quienes los arman a partir de hojas vírgenes de la planta, compran tabacos ya elaborados y los humedecen con esencias y mejunjes particulares de cada curador. Lo mismo sucede con el mambe, el ambil y la chicha; en la medida en que son resultado de complejas preparaciones que involucran "la fuerza y el pensamiento" de quienes los preparan, saben diferente porque su preparación siempre conlleva un propósito singular.

Para identificar la disposición espacial de los participantes en una reunión de esta comunidad en la maloca, no hace falta observar, solo saborear. En un inicio, cuando apenas empezaba a entrar tímidamente a la maloca, con torpeza y sin nunca haberme metido un cigarro a la boca, mi participación solo era visual, pasiva. A medida que ingresaba en su mundo cotidiano, mi boca se fue familiarizando con el sabor del tabaco, y a la vez aprendí a identificar tantos sabores como

69 Una primera versión de esta cartografía fue publicada en Gómez Montañez (2011a). 
abuelos conocía. Con el tiempo pude darme cuenta de que maloca quedaba dividida en dos regiones de acuerdo con la relación práctica-participante; claramente, la distribución de las personas señalaba relaciones de poder en torno a la herramienta espiritual (el tabaco). De un lado, los asistentes efímeros, curiosos y novatos, para quienes el sabor del tabaco era ajeno a su mundo. De otro lado, los sabedores e iniciados; por lo general, los primeros se sentaban más lejos de los abuelos que los segundos (figura 1).

Pero en general la maloca era un convite; cada abuelo compartía lo que había preparado. De modo que el sabor del tabaco podía atenuarse o intensificarse con el de la chicha, el mambe o el ambil. Entonces me di cuenta de que el tabaco traído por cada uno subdividía el espacio curativo. Unos tabacos eran dulces y otros amargos. Y sentir uno u otro sabor, en primera instancia, significaba una conexión con el abuelo sanador. Por eso, era común escuchar de una abuela: "Este tabaquito es bonito". Con eso, la abuela se refería a que su sabor era suave y no tenía otra intención que crear lazos de unión y de bienestar, así como traer pensamientos "sanos" y "alegría". Pero en otras ocasiones escuché decir: "Estos tabacos son para coger a todos a pata limpia"; significaba que eran para la "curación fuerte", por lo que su sabor se

Figura 1.
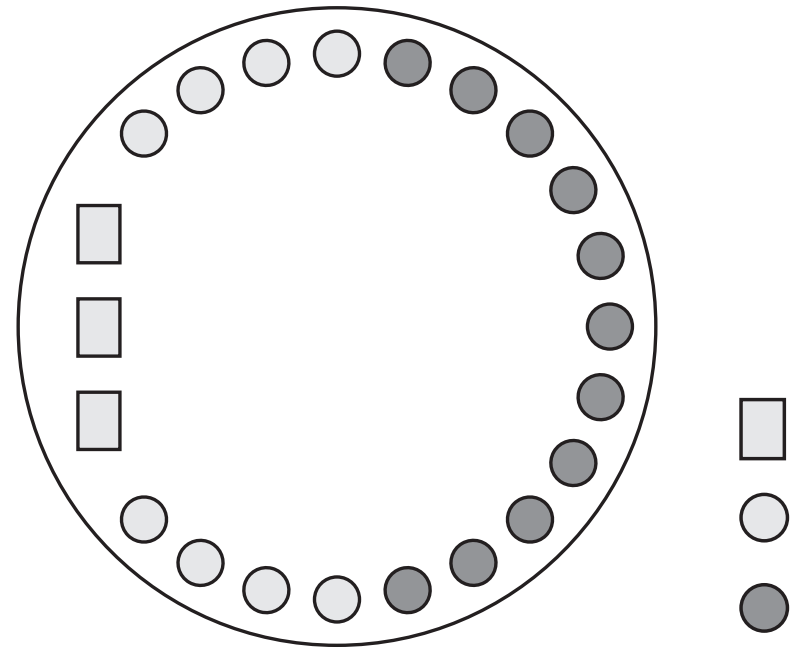

Abuelos

Conocedores del sabor del tabaco No conocedores del sabor del tabaco

Fuente: Gómez Montañez (2011a, p. 70). 
Figura 2.

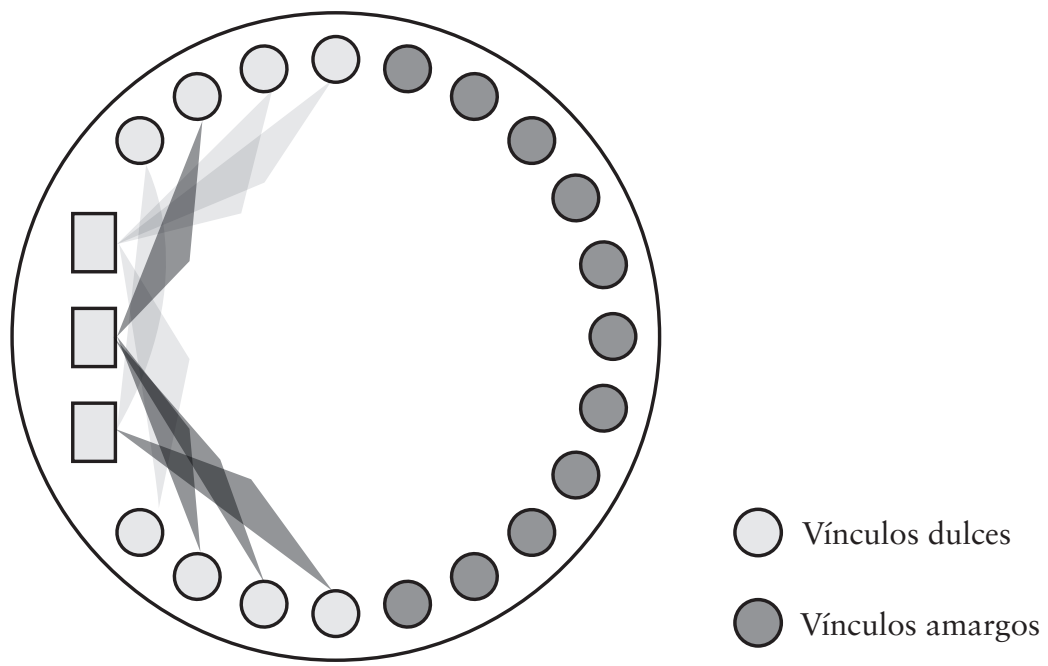

Fuente: Gómez Montañez (2011a, p. 71).

tornaba extremadamente amargo y nauseabundo, hasta el punto de producir desmayos o regurgitaciones.

Así como en el plano físico se puede establecer esta cartografía entre quienes conocen y no el sabor del tabaco, podemos también elaborar una que está sobrepuesta y que ocurre en el plano espiritual (figura 2). En esta, a partir de los testimonios, se trazan relaciones entre quien consume el tabaco y su maestro iniciador. Por consiguiente, el ethos que se configuró en estas redes dictaminaba que cada practicante debía conectarse energéticamente ${ }^{70}$ con su abuelo y "cuidar su palabra”, de esta manera cada vínculo representaba pertenecer a uno u otro linaje espiritual de los sabedores.

Esta segunda cartografía explicará en adelante varios espacios conflictivos. Por un lado, veremos que prender un tabaco o consumir

70 El calificativo energético empleado para referirme a este tipo de intercambios de tipo intangible y de dimensión "espiritual" se inspira en la afirmación de Mauss (1971/1929) sobre las "fuerzas” y "energías" que el don trae y despliega en su trasegar. Conectarse energéticamente con el otro, en nuestro contexto, significa vincularse con el plano intangible e "indecible" de las prácticas medicinales indígenas. 
cualquier planta sagrada en un lugar determinado significa activar fuerzas y energías que pueden entrar en conflicto con las energías que gobiernan el lugar, según los abuelos indígenas que la comunidad anfitriona siga. Por ejemplo, en una ocasión en la que me encontraba en el cusmuy de Bosa, comunidad que recientemente se identifica con la palabra y el linaje espiritual de ciertos mamos y jades de la Sierra Nevada de Santa Marta, no permitieron que una líder de Suba y yo prendiéramos tabaco. Normalmente, para hacerlo, se debe pedir permiso al líder anfitrión.

La reglamentación de cada casa sagrada es tan particular que las exigencias de los anfitriones pueden llegar a violentar al visitante o, todo lo contrario, indicarle que es aceptado como parte del tejido energético del lugar. Más adelante veremos que respecto al acto de ofrecer chicha, su aceptación o no en un evento específico, y dependiendo de cuál comunidad lo lidere, es un indicador de exclusión o inclusión.

Bien, pero hay que decir algo más sobre el tabaco, y es que debido a su uso diferencial en cada comunidad, se puede reprender a quien no lo haga correctamente $y$, en consecuencia, enseñar acciones correctivas. Aquella noche entera que pasé en el cusmuy de Chía preparando ambil, el abuelo Manuel Socha me regañó por prender mi tabaco con un encendedor; debía hacerlo directamente con leña del fuego central, o de lo contrario "ese abuelo [el fuego] se ofendería". El abuelo también me contó que en una ocasión en que recibió a un grupo de autoridades en el cusmuy, entre los que se encontraban los de PNMC, al ver que Yanguma "encendía un tabaco tras otro", le "quitó el tabaco" y, según él, la "puso en orden”. Cuando le pregunté a ella misma por este evento, me dio su versión y, de paso, me aclaró su interpretación acerca de los órdenes morales que están implicados en el uso de dones y su relación con los espacios, anfitriones y visitantes.

Cuando yo te invito a mi casa, y tú te vas a rapear [fumar] un tabaco, yo dejo que lo hagas como a ti te gusta. Si te gusta despacito, o si te gusta con caña, o si te gusta con pipa, es tu problema. Pero nunca te lo voy a sacar de la boca como me lo hizo él [...] me lo sacó de la boca y lo botó con rabia al fuego. Si conociéramos verdaderamente lo que significa eso. Yo fui respetuosa, era mi primer 
tabaco que me iba a chupar. No había prendido nada más, era el primer tabaco que iba a prender. Yo prendo siempre el primer tabaco para saludar a los espíritus del territorio. A mí me enseñaron mis ancianos que cuando uno todavía no tiene bien la palabra, uno rapea un tabaco para que esa palabra madure. A mí nunca me han enseñado a guerrear con tabaco. Ahora, él no me estaba irrespetando a mí, estaba irrespetando al abuelo tabaco. (Janeth Yanguma, 11 de mayo del 2012)

Por otro lado, la segunda cartografía nos permite entender que en el plano mágico y espiritual, aquella dimensión intangible en la que se mueven y fluyen las energías y fuerzas de los dones, se presentan retos y batallas. La misma Yanguma me comentó que en una ocasión en la que hubo un encuentro con indígenas del Amazonas y del Putumayo en la maloca, un participante "la haló" con su tabaco y la "chumó", es decir, le causó náuseas, porque la había "cogido desarmada". Aunque afirmó no "saber guerrear con el tabaco" y me expuso sus ideas éticas sobre el asunto, Yanguma también me contó que en otra oportunidad "sacó sus herramientas de su mochila" y que "ahí sí pudo protegerse".

Hasta ahora podemos inferir que el uso de la maloca del jardín botánico posibilitó un espacio para que la palabra huitoto del taita Víctor se transmitiera mediante herramientas espirituales como el tabaco y la coca. De igual forma se desplegaron otras redes de entregas con la chicha en cuanto don y se configuraron códigos de respeto y protección en las redes de iniciadores e iniciados. Así se fue configurando un ethos que se adecuaba y transformaba de acuerdo al papel que cada quien quisiera tener en el tejido espiritual y medicinal muisca. Para Sigifredo Niño Rocha y PNMC, todo esto significó su posicionamiento como líder y el fortalecimiento como organización y comunidad indígena alternativa que confrontaba el oficialismo de los cabildos. Aunque la comunidad de Ráquira formó parte de los primeros grupos asistentes a los espacios medicinales de la maloca, aquellas palabras del taita Víctor con las que se refería a que al principio no encontraba a los muiscas son empleadas por los líderes de PNMC para justificar que su trabajo con el anciano fue el primer contacto que él tuvo con el pueblo muisca que tanto esperaba. Esto inició en el 2005, luego 
de que la maloca permaneciera cerrada por varios años y fuera usada como bodega de almacenamiento de herramientas. Su reapertura y la conformación de nuevas redes de medicina y palabra indígenas lideradas por el taita Víctor hicieron que Sigifredo, Suaga Gua, líder de PNMC en Bogotá, se consolidara como líder muisca. Para su hermano Rodrigo Niño Rocha, Xieguazinsa, líder de PNMC en Boyacá, los espacios en la maloca coordinados por Sigifredo aportaron una serie de rutinas, repertorios y mercados del lenguaje que comenzaron a establecerse y a consolidarse en el campo etnopolítico muisca. El manejo de este tipo de versiones narrativas también corresponde con formas de anclaje moral e histórico empleadas por diferentes líderes muiscas en el tejido de transacciones.

[...] entonces se acerca el 2005 y Suaga Gua no sé por qué razón se relacionó con este anciano y él vio en nosotros algo distinto. Y entonces ya el anciano se conoce con Suaga Gua y nos dice que le ayudáramos a sacar adelante la maloca. Entonces empezamos nosotros con él a acompañarlos y a gestionar y, efectivamente, se volvió a pisar la maloca, se arregló, se sacaron todos esos depósitos de allí y se hizo toda la ceremonia [...] Entonces ahí empiezan las cosas de nosotros de vincularnos a la maloca. Y Suaga Gua empieza a abrir los círculos de palabra. La frase de "círculo de palabra" nace es con nosotros. Nace ahí. Eso antes nadie hablaba de ese tema, en esos términos. Es ahí cuando nosotros hablamos del círculo de palabra. Y se empezó que el tema de los círculos de palabra, inclusive acá en las instituciones todo el mundo habla del círculo de palabra y todo lo que ha pasado de allá para acá, que ya Suaga Gua es el que ha estado más al frente. (Rodrigo Niño Rocha, 18 de diciembre del 2011)

Los líderes de PNMC se integran a la narrativa con el papel de verdaderos continuadores del trabajo y la entrega de dones del taita Víctor. A su vez, se adjudican la autoría — si se acepta el término- de ciertos conceptos comunes hoy en día en el mercado del lenguaje muisca. Sigifredo, Suaga Gua, corrobora la versión de que fue el trabajo de PNMC el que instauró espacios popularmente conocidos en el campo muisca como los "círculos de palabra”, además dibuja una cartografía 
y hace un diagnóstico del proceso étnico de los muiscas desde la perspectiva de su propia organización.

Y yo hago unos interrogantes que son importantes de definir, y es ¿por qué después de veintiún años de creados los cabildos están apareciendo hasta ahora los cusmuy, los consejos de mayores, los términos como chyquys, abuelos y los jades, todos esos términos? Eso tiene que decir algo muy serio sobre el tema de Pueblo Nación Muisca Chibcha. Eso empieza cuando nosotros comenzamos a hacer la dinámica en la maloca del Jardín Botánico de Bogotá. Si no, investiguen cuándo apareció la casa espiritual en Bosa, cuándo aparece la casa de Cota, dónde estaban los sabedores de Sesquilé, cuándo aparece la casa espiritual en Chía, ¿sí? ¿Qué han hecho los de Suba con veintiún años de experiencia en su trabajo muisca? Hasta ahora están hablando de sunas, ceremonias. (Sigifredo Niño Rocha, 19 de agosto del 2011)

El fragmento del testimonio de Sigifredo no solo representa un dato cualitativo respecto a cómo un líder y su grupo se leen e interpretan a sí mismos en el tejido conflictivo, también es una fuente que recoge algunos criterios que operaron en él para manifestar su ethos, y desde ahí diferenciarse de otros y juzgarlos; de esta manera Sigifredo desafió a las comunidades oficiales mientras consolidaba su liderazgo. Sin embargo, los conflictos suscitados por la manera como manejó la maloca del taita tienen origen en aquellos conflictos que provocó su ingreso al campo etnopolítico muisca como gestor cultural, asesor y, luego, autoridad espiritual. En el siguiente apartado comprenderemos que los intercambios de tabaco, coca y chicha no fueron las únicas transacciones que configuraron el campo de conflictos morales, sino que hubo otras de tipo político y administrativo que conectaron la maloca con otros escenarios de pugna, acrecentando así la enfermedad y el desorden, causas de su cierre. 


\section{La ortiga de Suaga Gua: anclajes e incursión de Sigifredo en lo muisca}

Lo primero que se infiere del testimonio anterior de Sigifredo, Suaga Gua, es que el liderazgo que tomó PNMC en la maloca construida por el taita Víctor consolidó esta organización como un epicentro representativo de lo espiritual. Un primer componente de su ethos corresponde con el modo en el que narra y justifica la consolidación de su liderazgo en cuanto autoridad indígena mientras desafió y confrontó el estatus de los líderes y comunidades oficialmente reconocidas como las aparentemente "verdaderas muiscas". Aunque Cota y Sesquilé también se habían consolidado con espacios fundamentales de la red medicinal, el jardín botánico se caracterizó por el gran impulso que le dio al proceso de recomposición cultural indígena ante una población amplia y diversa de la ciudad. Durante la primera fase de mi trabajo de campo (2007-2009), esta maloca congregó a varias personas que emprendieron su camino hacia el autorreconocimiento étnico a través de los espacios medicinales y, en estos, la serie de iniciaciones en el manejo del tabaco, la chicha, el ambil y el mambe, desarrolladas junto con las enseñanzas y los procesos liderados por el taita Víctor y Sigifredo (Gómez Montañez, 2009). Incluso llegué a ver entre sus participantes a miembros de comunidades muiscas oficiales que luego transitaron a las figuras de abuelos y líderes espirituales en sus localidades. Sin embargo, las diferentes versiones sobre la permanencia y asistencia a estos escenarios por parte de cualquier miembro de la red étnica revelan diferentes configuraciones del ethos desde las cuales los papeles y las jerarquías se transforman. Pero en común tienen la idea de que la maloca representó la entrega de los dones medicinales devueltos por las culturas del Amazonas y el respectivo cuidado y respeto que se les debe a la palabra y al linaje espiritual del taita Víctor Martínez Taicoma.

Sigifredo no duda en exponer parte de su ethos y juzgar en cierta manera la demora de otras comunidades en ingresar al campo de prácticas espirituales, el cual se convirtió para muchas personas en la base del verdadero "despertar muisca" y del proyecto etnopolítico. Si bien él sugiere que PNMC influyó en dicho ingreso o motivación luego de más de veintiún años de consolidación de la etnicidad muisca 
en las comunidades oficiales, estas, por medio de algunos de sus representantes, configuraron otro ethos que corresponde a una versión diferente de los hechos. Desde el punto de vista de las comunidades oficiales, Sigifredo Niño no fue más que una persona oportunista que sin tener el respaldo de una verdadera comunidad indígena se aprovechó del poder de convocatoria de la maloca y de otros escenarios en las comunidades oficiales para validarse y nombrarse legítimo representante de las comunidades muiscas y autoridad espiritual. De esta manera, las palabras muisca y autoridad, sobre todo representadas en el cargo de chyquy, asumido por Sigifredo, y adicionalmente su nombre espiritual Suaga Gua, posibilitaron el establecimiento de unas diferencias en el primer nivel de conflicto moral expuesto anteriormente. Por su parte, Sigifredo afirma con contundencia que "ser muisca no es una cuestión de saber, sino de ser" y que por esa misma razón esencial él es “un abuelo independientemente de lo que los demás piensen”. Un día, retomando la historia de sus iniciaciones en el campo chamánico de la mano de comunidades indígenas mexicanas y la construcción de su nombre sagrado, Suaga Gua ('Hijo del Sol al servicio de la Madre') - a través del cual estableció vínculos con la vereda de Suagá donde sus abuelos lo criaron y lugar al que le atribuye una fuerza espiritual proveniente de los linajes sacerdotales muiscas-, Sigifredo, en un espacio de debate académico en el que también estaban presentes líderes de cabildos oficiales, varios de ellos detractores suyos, con firmeza dijo que "eso lo hacía ser chyquy". Además, interpreta que las demás comunidades y líderes no aceptan que el proyecto de PNMC tiene la misión de confrontarlos y "sacudirlos". Para anclar su papel e imagen de líder al relato de la historia reciente del pueblo muisca, incluso emplea la metáfora de la ortiga, planta usada como medicina y para castigar, ya que por sus características urticantes produce gran picazón e inflama la piel. Él mismo recuerda cómo elaboró esta comparación frente a varios líderes muiscas en una reunión llevada a cabo en Cota:

Les dije: "Hermanos, el problema de Pueblo Nación Muisca Chibcha ustedes no lo han entendido [...] nació a la orilla del camino, un camino que ya estaba trazado, que abrieron ustedes, y nace como una plantita que se llama "ortiga", y cuando el camino 
se va angostando, la ortiga se va avanzando hasta que le roza los tobillos y eso pica como un berraco. Entonces a eso toca buscarle la medicina, porque Pueblo Nación se convirtió en eso, en la ortiga de los mismos pueblos muisca. (Sigifredo Niño Rocha, 19 de agosto del 2011)

Sigifredo, Suaga Gua, al igual que su hermano Rodrigo, Xieguazinsa, considera que el proyecto de PNMC comenzó hace treinta y cinco años, cuando un grupo de personas que habían transitado por sistemas de pensamiento indígena en los años setenta se comprometieron a recomponer la cultura del pueblo muisca. Influidos por el indigenismo, este grupo de personas también decidieron autorreconocerse muiscas sin tener una comunidad indígena que los respaldara. Cuando ya casi concluía su adolescencia, Sigifredo viajó hasta México y allí conoció abuelos de grupos indígenas que lo iniciaron, según él, como chyquy. Una vez que regresó a Colombia, estudió administración deportiva, pero nunca la ejerció. Decidido a convertirse en un líder espiritual, basándose en sistemas de pensamiento indígenas y otros por los que transitó en su juventud, se dedicó a dictar charlas sobre temas atinentes. Su esposa Janeth Yanguma, considerada la abuela mayor de PNMC, recuerda que se conocieron cuando él dictaba conferencias sobre "conocimiento y sabiduría" en la localidad de Engativá, al occidente de Bogotá, en el año 1985. En ese entonces se presentaba como Sigifredo y no con su nombre de abuelo espiritual, Suaga Gua.

Sigifredo, acompañado por Janeth y su hijo recién nacido, comenzó a organizar los primeros círculos de palabra en una pequeña construcción circular en piedra, ubicada en la parte alta del bosque del parque nacional Enrique Olaya Herrera, de Bogotá. Se denominan “círculos de palabra” los espacios en los que los líderes y seguidores de prácticas indígenas renovadas se reúnen a compartir ideas y medicina. Para quienes no podían ser miembros de las comunidades muiscas que oficialmente se consolidarían una década después, los círculos de palabra fueron espacios efectivos de convocatoria y reproducción social de grupos y redes que, desde la práctica de la medicina indígena, configuraban comunidades y organizaciones basadas en el neto autorreconocimiento étnico o, por lo menos, en la integración de estilos 
de vida imaginados como indígenas, es decir, estilos basados en representaciones de lo indígena elaboradas por personas de la clase media de la ciudad.

Sigifredo vivía entonces en la localidad de Engativá, cerca al humedal Jaboque. Como fiscal de la JAC de esta localidad, adelantó diligencias para proteger este ecosistema amenazado por empresarios del sector de la construcción. Al presidente de la JAC lo asesinaron por orientar su liderazgo en tal empresa y Sigifredo fue amenazado, por esta razón decidió irse a vivir a la localidad de Suba. Con miras a consolidarse como líder y aportarle, según él, al “despertar” y a la recomposición del pueblo muisca, se dirigió al cabildo indígena de esta localidad. El cabildo no poseía personería jurídica y había perdido su reconocimiento étnico por parte del Ministerio del Interior. Existía un conflicto muy fuerte entre el gobernador Antonio Torres y el exgobernador Roberto Galvis Bulla, a tal punto que se afirmaba que prácticamente "había un doble gobierno en Suba". A su manera, Sigifredo cuenta que se acercó al gobernador Torres y le dijo: "Yo no veo nada muisca acá". Colaboró entonces con la limpieza de la oficina del cabildo, la cual quedaba en el tercer piso de un edificio. Se convirtió en cierta manera en un asesor del cabildo; sugirió que la sede estuviera cerca de la plaza de gobierno porque la autoridad indígena debía "estar a la misma altura" de la alcaldía, la iglesia y la policía local. Por esta razón, según su versión, él influyó en la consecución de la actual sede del cabildo, cercana a la plaza principal de Suba. Así, se ganó la confianza del gobernador y consolidó su liderazgo con una propuesta muy concreta que le hizo:

Yo le decía al primer gobernador en ese momento: "Hermano, si quiere, yo le ayudo; me nombra director de proyecto, a cero pesos, y lo único es que usted, cuando salga un proyecto, me da la coordinación". Me dice: "Listo", y empecé a hacer proyectos.

(Sigifredo Niño Rocha, 19 de agosto del 2011)

Como el cabildo no tenía personería jurídica, se canalizaron los recursos por la Casa de la Cultura de Suba. Durante tres años se instauró y desarrolló el Programa de Fortalecimiento de la Cultura Muisca. De esta manera, Sigifredo comenzó a establecer vínculos laborales con los cabildos muiscas y agenció los escenarios de recuperación 
cultural para consolidar su imagen de autoridad espiritual. Por aquel tiempo, una joven bogotana de linaje materno arhuaco cambió su nombre de pila por Ati Quigua y comenzó su carrera política como candidata al Concejo de Bogotá. Las comunidades indígenas de la ciudad, por supuesto, constituían un importante banco de electores, por lo cual ella buscó gestionar proyectos con los cabildos para fortalecer sus alianzas y garantizar su apoyo político. Debido a que Ati Quigua no fue posesionada como concejal por ser menor de edad, Sigifredo y el Cabildo Muisca de Suba lideraron una protesta en la plaza del Concejo de Bogotá. Su alianza se fortaleció por medio de la gestión de recursos para ejecutar proyectos etnoturísticos en Suba. En esa época, el gobernador Antonio Torres ya era cuestionado por su comunidad por asuntos de manejo de dineros de proyectos, y por ende, Sigifredo salió afectado, pues también fue juzgado como una persona que se apropió de recursos de los proyectos y se benefició personalmente.

Myriam Martínez Triviño, exgobernadora de Suba, relata en su testimonio la manera como la imagen de Sigifredo ha sido en cierto modo transmitida a los nuevos líderes de Suba que también comparten una memoria sobre la dudosa gobernación de Antonio Torres:

Lo que tengo conocimiento es que en un momento dado se acercó al gobernador Antonio Torres, que en ese entonces estaba a cargo, le pidió el favor de que firmara, no sé como fue el tema, pero él dijo que venía de Cota, Chía, Sesquilé, de otras comunidades que eran hermanas de nosotros y que ellos lo habían enviado para hacer un trabajo cultural y no sé qué. Entonces el gobernador le dijo: "Claro, sí, vamos a trabajar con el tema cultural”, y le dieron una certificación para que trabajara el tema cultural, pero dejando claro que no es de este territorio y de nuestra comunidad muisca. (Myriam Martínez Triviño, 24 de septiembre del 2011)

Pese a la aclaración que cuenta Myriam sobre la relación de Sigifredo con la comunidad muisca, él, o mejor dicho Suaga Gua, fue certificado autoridad espiritual de Suba por el gobernador de turno. A lo largo de esta narración veremos que la certificación corresponde a una manera de reconocer temporalmente el estatus de una persona, pero también a un modo de invalidar sus acciones. Aunque su imagen causaba 
polémica, Sigifredo pudo ingresar a algunas comunidades como gestor de proyectos de recuperación cultural. De acuerdo con lo que nos contaba Myriam, Sigifredo nunca fue considerado ni muisca de una comunidad determinada ni menos una autoridad en el plano espiritual. Sin embargo, en nuestra primera charla, Myriam me comentaba que su guía espiritual, el abuelo Ignacio, siempre le decía que para hablar con Sigifredo había que tener cuidado. En una ocasión, cuenta Myriam, el abuelo Ignacio le dijo: "Gobernadora, cuando se siente con él, cierre su cuerpo o, si no, la vuelve ropa de trabajo". En efecto, la imagen de Sigifredo también oscilaba entre la de una persona de dudosa identidad étnica y la de una persona poseedora de energía poderosa en el plano mágico y espiritual, aunque de algún modo temible. Este tipo de juicios negativos lejos de excluir a Sigifredo de la red étnica, lo integran como un aportador energético a quien hay que controlar y de quien hay que protegerse.

Gracias al apoyo político brindado a Ati Quigua en un momento, Sigifredo conoció a Alfonso Fonseca Balsero, entonces gobernador del Cabildo Muisca de Cota, con quien llegaron al acuerdo de formar una consejería cundiboyacense con el fin de fortalecer los procesos etnopolíticos de la región — trato invalidado verbalmente por Alfonso varios años después-. Alfonso Fonseca y Sigifredo y Rodrigo Niño Rocha quedaron a su vez como representantes de Cundinamarca, Bogotá y Boyacá, respectivamente. Bajo esa figura continuó apoyando a Ati Quigua e, incluso, según él, asesoró la creación de los estatutos de varios cabildos indígenas de Bogotá que, como el quichua o el pijao, requerían organizarse administrativamente, además que representaban más fuerza electoral para la joven política indigenista recién autorreconocida arhuaca. Otra de sus iniciativas fallidas fue tratar de unir al pueblo muisca en una sola organización étnica al igual que lo habían hecho otros grupos étnicos de otras regiones colombianas. Algunos testimonios afirman que en el año 2002 se trató de constituir el Cabildo Mayor Muisca. Mientras que Carlos Candil, de Sesquilé, me dijo que la idea era que Carlos Mamanché fuera su presidente, Heseen Yopasá, de Suba, afirmaba que ese liderazgo estaría en Bosa. Por su parte, Rodrigo, hermano de Sigifredo y líder de PNMC en Boyacá, en una ocasión me comentó que en el marco de los vínculos con Alfonso Fonseca Balsero, 
de Cota, nació la idea de conformar la Nación Chibcha Muisca, y que incluso el mismo Fonseca Balsero había participado en el diseño del logo de PNMC. Por supuesto, fue esta organización la que decidió identificarse con el nombre de nación, aspecto del que disienten los cabildos oficiales por el carácter arrogante y las ideas de homogeneidad e ilegitimidad que PNMC representa para muchas personas.

Aunque Sigifredo reconoce que cuando entró en contacto con el Cabildo de Cota lo hizo por medio de lazos con personas de "la parte política", lo cierto es que logró ser certificado por gobernadores como autoridad espiritual o chyquy y que tales certificaciones firmadas por él las soporta papelería membreteada de los cabildos que reposa en el archivo de PNMC. Ante esto, Alfonso Fonseca prefiere referirse a Sigifredo como un simple gestor cultural y colaborador en determinado momento sin mayores vínculos con las comunidades muiscas.

A Sigifredo lo conozco como cuando comencé de gobernador. Vino alguna vez, se presentó. Sigifredo, no sé en qué trabajaría, se le ve lo mismo que tal vez nos ha pasado a nosotros pero en oficios diferentes. De pronto fue ingeniero o de pronto fue portero, no sé. Sino que a medida que ha pasado el tiempo se ha metido en lo indígena, pues ha seguido profundizando. Él vino y se presentó acá, que ya manejaba unas cosas de tabaco y alguna cosa espiritual, algunos rituales y que nos servía como consejero. Venía común y corriente, a veces con una blusita blanca ahí. Dictando alguna vez como un taller de políticas públicas o algo así, eso fue como en el 2004, 2005, y alguna vez lo invitamos al cabildo para que nos contara rituales y cosas y que qué hace con el tabaco. Y a medida que yo lo he conocido, pues tiene su palabra, tiene sus cosas, su punto de vista desde lo muisca. Pero él no ha sido de ninguna comunidad, lo ha venido a asumir él. (Alfonso Fonseca Balsero, 22 de junio del 2012)

A las versiones que lo califican de oportunista y lo identifican como gestor cultural se suman otras que testifican un tránsito en su apariencia. En el video que Sigifredo me facilitó, sobre un proyecto de recuperación cultural en Suba, aparece vestido con sudadera y luce pelo corto, pero cuando lo conocí, vestía de blanco, tenía el pelo largo, 
portaba collares y mochila y se presentaba como chyquy. Para el abuelo Fernando Castillo, de Cota, ese tránsito está relacionado con la posibilidad de conseguir dinero y con la necesidad de legitimar un conocimiento sobre lo indígena basado en el contenido de libros, aspectos que analizan constantemente los miembros de los cabildos oficiales para cuestionar la autoridad de los chyquys de PNMC.

Fernando: Por eso le decía al principio que a mí me preocupa la situación de ahorita porque sí aparecen muchos personajes, pero verdaderamente ¿cómo es? Que conocen por medio de los libros, de lo que han leído por ahí, de lo que está escrito, pero tener, digamos, una preparación, conocimiento, una conexión verdadera con la naturaleza y pensarse internamente con lo natural $[\ldots]$

Pablo (investigador y autor): ¿Cuál fue la primera referencia que tuvo de PNMC?

Fernando: Yo de ellos no puedo decir nada. Sigifredo y el hermano llegaron en algún momento aquí y como está usted, conversando igual y tatatá... "abuelo, que para esto y lo otro, que para un trabajo". Llegaron en esas condiciones... "estamos formando también un grupo para colaborar con ustedes" y no sé qué y tal...

Pablo: ¿Pero se le presentaron como chyquys?

Fernando: No, querían conocer, ni qué vestidos ni qué ocho cuartos... se les ocurrió ahorita último, por sentirse grandes. (Fernando Castillo y Pablo Felipe Gómez Martínez, 13 de abril del 2012)

Cuando le pregunté a Yanguma, esposa de Sigifredo, cómo interpretaba el tránsito de su esposo para presentarse como chyquy, me respondió que eso "había sido un proceso muy profundo e interno" y que correspondía a "algo normal en su proceso de búsqueda". Lo cierto es que Sigifredo logró agenciar y capitalizar la ambivalencia de su imagen que oscilaba entre la de gestor cultural oportunista y la de líder espiritual muisca, muestra de ello es que logró ganarse la confianza del taita Víctor para recuperar el trabajo espiritual y cultural en la maloca del jardín botánico. La versión de Sigifredo sobre cómo llegó a liderar los círculos de palabra en este espacio comienza con el día en que visitó 
el Jardín Botánico de Bogotá y encontró una maloca usada como bodega. Ante esta situación, le solicitó apoyo a Ati Quigua, y por medio del director de la institución en el momento de la construcción de la maloca, contactaron a Víctor Martínez Taicoma, el taita que había dejado su esencia allí. Su intención era saber por qué razón se había construido, pues sospechaba, de acuerdo con el conocimiento que tenía de las comunidades indígenas, que la construcción de este espacio sagrado siempre tenía un propósito de tipo cosmológico y ligado profundamente al plano espiritual y energético. Una fundación cultural financió su viaje hasta La Chorrera. Víctor, cacique maloquero de este corregimiento del Amazonas, le confirmó a Sigifredo y a otros líderes que la maloca había sido construida por él para despertar al espíritu muisca. Tiempo después, el taita convocó un encuentro para "pisarla" nuevamente, es decir, volverla a inaugurar y activar su poder medicinal —vinculado profundamente al poder de su constructor y aportadorpara que se consolidara como espacio de fortalecimiento étnico en la ciudad. Según Sigifredo, aunque en su momento fueron convocados los cabildos indígenas de Bogotá, incluyendo los muiscas oficiales, estos nunca aparecieron; solo PNMC, organización liderada por él y su hermano, se hizo presente, por consiguiente, recibió de parte del abuelo Víctor la tarea de manejar la maloca como epicentro del "despertar muisca”. Más adelante, con el cierre de la maloca, los cabildos oficiales y las redes espirituales conformadas por integrantes tanto de los cabildos como de otras organizaciones van a atribuirse la responsabilidad de cuidar la palabra y la medicina del taita Víctor Martínez Taicoma.

Sigifredo no niega el camino que abrieron las comunidades oficiales hacia el proyecto etnopolítico muisca, pero defiende la legitimidad de su organización, adoptando una actitud discrepante, arrogante y juzgadora. Tampoco niega haber capitalizado su conocimiento en gestión cultural en función de darse a conocer entre las comunidades oficialmente reconocidas, pero afirma su condición de chyquy. La oscilación entre su papel de gestor y su papel de autoridad espiritual, sumada a los juicios que ambas figuras suscitan, van a marcar una serie de procesos conducentes a que su labor sea apoyada por unos pero también objetada por otros debido a los conflictos inconmensurables que genera. Cierto es que había logrado conquistar un espacio en la 
maloca para consolidar su imagen de autoridad espiritual indígena, sin embargo, las respuestas, a veces de aceptación y otras de rechazo, por parte de líderes y miembros de las comunidades oficiales participantes de este espacio trascendieron a escenarios políticos.

El hecho de declararse chyquy y llevar sobre su espalda rumores de corrupción condenó a Sigifredo a vivir entre la sospecha y la desconfianza y a enjuiciar con un aire jactancioso. Su liderazgo y gran capacidad oratoria lo llevaron a representar a las comunidades indígenas ante un consejo comunitario organizado por el entonces presidente Álvaro Uribe Vélez, que tuvo lugar en el 2006 ante comunidades indígenas del centro del país, en la plazoleta de los Artesanos, de Bogotá. Su hermano recuerda que allá Sigifredo hizo llover cuando nombró el espíritu de la laguna que reclamaba el territorio que ocupa la plaza donde se desarrollaba la reunión (Gómez Montañez, 2009). En el marco del comunicado que Sigifredo leyó aquella vez, asesorado por el equipo político de Ati Quigua, obtuvo la presidencia de la naciente y efímera Consejería Indígena Cundiboyacense. Ganó esta presidencia debido a un choque de modos de interpretación respecto a las formas de poder indígenas. Según como lo cuenta Sigifredo, debían llegar a un consenso entre todos los representantes de comunidades, pero los otros representantes propusieron el método del voto. Cuando a Sigifredo le correspondió votar, su candidatura empataba con de la Reinel Neuta, entonces gobernador del Cabildo Muisca de Bosa, por lo tanto, votó por él mismo; ganó, pero eso no le gustó para nada a sus detractores, quienes lograron comenzar a transformar las percepciones de Ati Quigua sobre él y su organización PNMC. Por esa razón, cuenta él mismo que en una reunión a la que no fue convocado lo sacaron de la Consejería y Ati Quigua fundó la hoy llamada Ascai (Asociación de Cabildos Indígenas de Bogotá). Al estatuir que a dicha asociación solo podían pertenecer las comunidades oficialmente reconocidas por el Estado, PNMC quedó excluida de los espacios políticos y de participación indígena que Ascai hacía posibles. Tal exclusión se intensificó cuando los cabildos oficiales comenzaron participar de manera más comprometida y permanente en la ONIC, algo que PNMC, por su carácter diferencial y alternativo, no podía hacer. Y en efecto, así fue; cuando Sigifredo y Rodrigo lograron tener vínculos con una 
persona de la ONIC con la intención de ingresar a esa organización o de participar en alguno de sus espacios, fueron literalmente "bajados del bus”. Esta expresión alude a la vivencia de Rodrigo cuando fue invitado a participar en un encuentro de la Mesa Macro-Oriente de la ONIC y los líderes muiscas al verlo subir al bus que llevaría a los representantes al lugar del evento fuera de Bogotá, armaron un boicot, logrando así evitar su presencia.

Además, la rivalidad entre Sigifredo y Ati Quigua por el control de la maloca se agudizó. Su enemistad se acrecentó y llegó a puntos de inconmensurabilidad, que incluso Sigifredo y Rodrigo no dudan en interpretar que varias situaciones en las que vieron amenazada su integridad las causaron influencias políticas de Ati Quigua y posibles relaciones con actores y espacios donde aparecían sospechosos métodos de exclusión. Rodrigo me comentó en más de una ocasión que cuando "se calentaron las cosas con Ati Quigua", una vez unos "personajes muy extraños" lo abordaron y le advirtieron que no se involucrara en ciertos asuntos en los que la concejala estaba interesada. Por su parte, Sigifredo me contó que una frase contundente de la política en una reunión fue: "Hay que acabar con todo lo que huela a Pueblo Nación Muisca Chibcha”. Igualmente, veremos más adelante que el campo conflictivo de la red étnica muisca de curación y espiritualidad comenzó a ser reconfigurado en ocasiones y momentos por lenguajes de guerra y de violencia política.

La relación entre Ati Quigua y los cabildos oficiales se fortaleció, según Sigifredo, porque su madre era la directora de DGAI del Ministerio del Interior. Gracias a ello, la institucionalidad estatal facilitó el proceso para que los cabildos muiscas recuperaran su certificación. Para Sigifredo, esto no fue más que un proceso "politiquero", pues la realidad es que, con excepción del Cabildo Muisca de Bosa, los demás cabildos en la actualidad están certificados por oficio o memorandos, pero no por resoluciones, aspecto que marca amplias diferencias en el marco jurídico. 


\section{El cierre de la maloca: medicina, violencia y negociación}

En la relación existente entre la memoria y el conflicto étnico, las soluciones de este corresponden a transacciones y reciprocidades positivas y negativas que les permiten al grupo y a los individuos reinventar sus instituciones y repertorios rituales para administrarlos y agenciarlos. De ahí que en el "despertar muisca” no solo se reactiven los mitos, tradiciones, creencias y órdenes morales respecto al pasado y los ancestros de larga data, sino además formas y prácticas tanto de violencia simbólica como de resolución de conflictos. Ambas, la violencia y la negociación, se relacionan directamente con el campo de prácticas, discursos e imágenes que los muiscas han construido y definido como espacios medicinales, los cuales unas veces corresponden a eventos ceremoniales como tales cuyo propósito específico es la curación y la limpieza; y otras veces, a una instancia que forma parte de cualquier reunión comunitaria. Esto último quiere decir que todo espacio de encuentro indígena donde se reúne la comunidad para escuchar la palabra de sus mayores siempre tiene un fin terapéutico y curativo, aunque a veces el objetivo de dichos encuentros sea discutir, planear o evaluar asuntos de tipo cotidiano, administrativo o político. Surgen así, por ejemplo, los consejos de mayores y los círculos de palabra como escenarios de denuncia, debate, diálogo y acuerdos, imaginados por los líderes muiscas como métodos indígenas de negociación y toma de decisiones. También es habitual que las reuniones que se llevan a cabo en las casas sagradas (cusmuyes, chunzúas o malocas) impliquen que el abuelo anfitrión o algún líder iniciado reparta su medicina a los asistentes para "armonizarlos". Por lo general, quien inicia la palabra del encuentro suele saludar a los padres y las madres creadores y a los espíritus del territorio, enseguida solicita que estos ayuden a sanar y a que los propósitos y compromisos que emerjan se den en buenos términos. El fuego se considera un poderoso abuelo espiritual que contribuye a la purificación al consumir "palabra y pensamientos calientes" relacionados con el "negativo" que toca superar para llegar a los acuerdos. 
El uso de la medicina por medio del consumo de plantas y las estéticas que involucra al incluir mochilas, collares, atuendos y otros elementos que contribuyen a reforzar la imagen heroica del guerrero y el chamán ${ }^{71}$ han hecho de la medicina un factor relevante de convocatoria e identificación para que muchos indígenas y no indígenas ingresen a las redes étnicas de curación y espiritualidad. A partir de los momentos extáticos y ontogénicos que se presentan en la renovada curación muisca, algunas personas encuentran nuevos anclajes con que vincularse a las narrativas del "despertar" y mediante estos buscan a la vez ocupar una posición en el campo de relaciones de poder que se tejen en dicho campo. Soñar con los ancestros indígenas o con los abuelos guía, tener visiones reveladoras que permitan tomar decisiones, lograr sanar a alguien y superar alguna enfermedad o situación problemática son algunas de las añoranzas de muchos y muchas integrantes de estas redes. Esto significaría confirmar y validar la participación de alguna persona en el tejido energético y poder ser reconocida como candidata a recibir un entrenamiento más profundo en medicina. Por esa razón sus integrantes suelen resaltar las relaciones que tienen con los abuelos y sabedores de sus comunidades y de otras etnias y, además, buscan ser iniciadas en el uso de plantas y en prácticas como el tejido.

Pero además, de ese mismo sustrato energético y poderoso de la medicina emergen batallas en los campos simbólico y onírico (Gómez Montañez, 2013a). En los estudios sobre chamanismo es común encontrar esta disputa entre los especialistas religiosos y en medicina indígena (James y Jiménez, 2004; Pinzón y Garay, 1991; Taussig, 2002; Vasco Uribe, 1985; Wolfson, 2004). Como lo enuncié en el apartado anterior con respecto a Sigifredo, si alguien percibe en otra persona una energía de la que hay que protegerse, eso significa que esta persona es de algún modo juzgada y excluida cuando se aplican ciertos ethos, pero termina siendo validada como influyente en el tejido energético. Por esa razón, cuando en mi trabajo de campo comencé a registrar relatos sobre guerras oníricas y otras que acontecían en el plano mágico

71 Me referí a los arquetipos héroe guerrero y héroe chamán en el apartado "El para qué de la memoria: itinerarios y tramas de sentidos” del cuarto capítulo. 
de la medicina, comprendí que estas eran juegos de lenguaje o "gramáticas sociales" (Wittgenstein, citado por Pearce y Littlejohn, 1997). Para Wittgenstein, las conductas o los comportamientos ocurren dentro de un contexto estructurado y se conectan dentro de formas específicas de vida (p. 53). Siguiendo las propuestas de Cliffort Geertz (1987), este tipo de guerras son maneras como algunas comunidades indígenas se interpretan a sí mismas, es decir, interpretan los mundos que han configurado por relaciones de diferente orden. En el caso de PNMC, los relatos y rumores sobre este tipo de violencias contribuyeron a configurarla como espacio social de relaciones y como objeto de juicios y prevenciones.

En el año 2010, cuando reanudé mi trabajo de campo con PNMC, muchas cosas habían cambiado. Algunos chyquys se habían separado del movimiento y las rencillas se tornaron aún más complejas, pues no solo había disputas por la interpretación del discurso espiritual de la reetnicidad muisca, sino que además los conflictos se basaban en distintos intereses políticos, administrativos y burocráticos en el marco de relaciones institucionales. Algunos líderes se acusaban mutuamente de no cumplir los principios éticos del llamado "despertar muisca". Expresiones como "contratitis", "estar embolatado", "perder el camino", "a qué juegan”, “neohippies” y otras alimentaron el repertorio de mis últimos registros de conversaciones informales.

Comencé a registrar sistemáticamente los historiales de charlas virtuales (chat) con varias personas que participaban en disputas, y quise encontrarme con diferentes líderes y agrupaciones para proponerles mi plan de trabajo investigativo en el marco de mi doctorado en antropología. Un día tuve la siguiente conversación con Édgar ${ }^{72}$, reconocido como taita o conocedor de lo curativo y espiritual, quien había sido integrante de PNMC o que por lo menos tenía relaciones cercanas y colaborativas con uno de sus líderes, llamado Floresmiro:

Pablo: Me llama mucho la atención la desunión... ¿ ¿cuál es el conflicto con Nación Muisca?

72 En la narrativa de este apartado emplearé los seudónimos Édgar, Floresmiro y Gabriel. 
Édgar: La magia negra, el mal uso de la herramienta, la gente enferma.

Pablo: ¿Por qué hay esa guerra? ¿Por qué no la unión para el “despertar muisca"?

Édgar: Poderes, manipulación, proyectos, nosotros no le jugamos a eso. No somos ni pertenecemos a Nación Muisca, nuestros procesos llevan más de 20 años y siempre han sido de cara a las comunidades. (Conversación virtual, 16 de septiembre del 2009)

Cuando le pregunté a Édgar si acaso a los círculos de palabra de PNMC en la maloca habían ingresado personas que comenzaron a hacer magia negra, contundentemente respondío que "nadie se había colado" y que incluso Floresmiro sabía quién de PNMC lo había "intentado matar”, pero que se “estaba haciendo el huevón”. Le pregunté si el ataque que había sufrido fue físico o si ocurrió en el plano espiritual, a lo que me respondió: "Herramientas, ataque al corazón y trombosis". Cuando conversamos personalmente en una ocasión posterior, me dijo que unos indígenas tubús del Vaupés que vivían en Bogotá y que acompañaban permanentemente los procesos de PNMC lo habían “operado espiritualmente" para ayudarlo y que "físicamente tenía una astilla en el corazón" que, según él, guarda en un frasco como recuerdo. La única explicación que Édgar daba a la presencia de una astilla en su corazón fue que era producto de una contienda en el plano espiritual, llamada también "trabajito".

Pude confrontar su versión con la del sospechoso perpetrador del ataque, con quien me encontré casualmente el mismo día de mi charla virtual con Édgar. Floresmiro corroboró y complementó el relato de Édgar, así contribuyó a configurar la gramática social que estructuraba los órdenes morales y el campo de poderes en el cual se dio esta batalla onírica. Floresmiro me dijo que una noche Édgar lo atacó con varias flechas en un sueño; esquivó todas menos una que alcanzó a perforar su garganta por la parte frontal, la quebró, y con la misma punta que lo hirió, lanzó un ataque al corazón de Édgar. Todo esto porque Édgar andaba diciendo que “icuáles abuelos!”, que Floresmiro no era ningún abuelo. Entonces Édgar tenía que ser "llamado al orden". 
Pero en su versión, contraria a la de Édgar, Floresmiro se "había defendido". Esa misma tarde agregó que si "él hubiera querido", habría "atacado fuerte", pero que después "tendría que pagar sus consecuencias". Édgar y Floresmiro configuraron un relato en el que se presentaron como personas capaces de manejar el espectro mágico e intangible de la medicina indígena para atacarse. A este tipo de situaciones entre miembros de la red étnica se sumaron otras en las que pude identificar el empleo de lenguajes de guerra y violencia política en medio de disputas. Nuevamente el nodo principal, la maloca del Jardín Botánico de Bogotá, es el escenario donde confluyen estas relaciones conflictivas. En este otro relato participa Gabriel ${ }^{73}$, quien transitó por Cota y recibió enseñanzas de Tigua Nika Sua y del abuelo José Pereira. Formó parte de PNMC, y cuando tuvo conflictos con sus líderes, comenzó a trabajar con la comunidad muisca de Bosa y abrió su propio círculo de palabra en una localidad de Bogotá, donde vive. Pero Gabriel, al igual que muchas otras personas de la red étnica, terminó formando parte también de la Fundación Carare, organización liderada por el taita Orlando Gaitán, otro protagonista de este relato. El taita Orlando Gaitán se autorreconoce como el último descendiente de los indígenas carare del Magdalena Medio y es un poderoso yagecero. Convoca en su sede de La Vega, municipio de Cundinamarca cercano a Bogotá, a numerosas familias mestizas que también optaron por reconocerse descendientes de pueblos indígenas y asumir un estilo de vida relacionado con el imaginario que han construido del nativo americano. Orlando fue premio alternativo de paz y tiene una amplia experiencia política en resolución de conflictos, y poco a poco se fue consolidando como un médico sanador que también cumpliría un papel fundamental en el "despertar muisca"; varios abuelos muiscas y de otras etnias del Amazonas y de la Sierra Nevada de Santa Marta lo llegaron a ver como un taita poderoso y aceptaron su medicina del yagé. Por su fama y contactos políticos pudo integrar el grupo de líderes que usarían la maloca del jardín botánico. Y es aquí, en este punto, en el que las

73 Uno de los miembros de la red étnica que caractericé como itinerante, es decir, sin comunidad fija, y que transitó por varios grupos debido a las disputas. 
vidas de Orlando, Gabriel y Sigifredo se cruzan para configurar otro mapa de la inconmensurabilidad.

Según Sigifredo, el taita Orlando Gaitán llegó a la maloca porque un miembro de su fundación era empleado del jardín botánico. Los conflictos entre PNMC y líderes indígenas de otras comunidades, como también con funcionarios de la institución, se iban agudizando; Sigifredo me contó que incluso descubrió en una de sus "consultas" con herramientas sagradas que una empleada, perteneciente a la etnia murui, lo estaba atacando con la intención de hacerlo enfermar. Cuenta también que cuando la confrontaba, ella negaba el asunto. De otro lado, según Gabriel, hubo conflictos entre Sigifredo y él debido a que varias personas y abuelos de PNMC estaban haciendo mal uso de la medicina. Lo explico: en uno de los últimos círculos de palabra de PNMC a los que asistí en la maloca, Gabriel denunció casos en los que hombres estaban "tabaqueando" a las mujeres. Lo más curioso para mí fue que, refiriéndose a estos casos, empleó las figuras medievales de los íncubos y súcubos, con las que la Iglesia católica se refería a los participantes de las orgías sexuales dentro de las prácticas de la brujería europea. Por supuesto, las versiones de los líderes de PNMC son diferentes. Lo cierto es que tales distanciamientos causaron que cada parte del conflicto se leyera así misma y juzgara a la otra de acuerdo a un criterio moral fundamental en el intercambio de dones, que hemos venido argumentando: quién estaba respetando o no la palabra y la medicina que habían sido devueltas por el taita Víctor Martínez Taicoma. En otras palabras, quién estaba devolviendo correctamente su palabra y haciendo circular armoniosamente su medicina. Gabriel se convirtió en el puente entre los taitas Orlando y Víctor.

La Fundación Carare de alguna manera comenzó a competir con PNMC por el liderazgo de la maloca y por el papel de receptor legítimo de los dones del taita Víctor. Según Gabriel, la fundación cumplió tareas que PNMC nunca hizo; cultivó sus propios tabacos y varios miembros viajaron al Amazonas a devolverle directamente al taita Víctor su palabra y medicina, mostrándole cómo ellos estaban preparando el ambil. Importa señalar que la administración del Jardín Botánico de Bogotá en ese entonces, año 2010, influenciada también por Ati Quigua, quien veía en la maloca un crisol de apoyo político indígena, decidió 
crear un consejo de la maloca. Esta figura más nominal que realmente con funciones de un consejo, fue conformada por los líderes de PNMC, Carare y otros grupos étnicos que deseaban usar la maloca como espacio de encuentros culturales. Así, se fijaron unos horarios y turnos de uso semanal. Como resultado, en la maloca construida por el taita Víctor, confluían distintos grupos que establecían relaciones de diverso orden con el taita, la institución, Ati Quigua y entre ellos mismos. A partir de estas relaciones en torno al nodo principal, la maloca, pude identificar un mapa del conflicto entre Sigifredo-PNMC y Gabriel-Fundación Carare. Antes de trazarlo, revisemos primero algunos datos obtenidos de la charla virtual que tuve con Gabriel el 17 de septiembre del 2010.

Cuando le comenté que sabía del cierre de la maloca ese mismo año Gabriel no dudó en responderme que "querían pasar por encima del abuelo Víctor, quien fue el que la construyó”. De esta manera Gabriel aplicaba el principio del respeto por la energía de un don tan valioso como era la maloca. Después me comentó que hubo muchas "alianzas perversas de los mismos muisca en contra del abuelito" y que incluso se aliaron estos y Ati Quigua para sacar al abuelo y al "taitica", refiriéndose a Orlando Gaitán. Cuando le pregunté a qué "muisca" se refería, respondió contundentemente que a los de PNMC. Según él, los de PNMC estaban adelantando gestiones ante la Alcaldía Mayor de Bogotá para quedarse con la maloca, intención que nunca le consultaron al taita Víctor. Por lo cual, Gabriel y otros aliados de la Fundación Carare, entre ellos los cabildos oficiales, habían hecho "una denuncia en espíritu ante el territorio". Luego, en su testimonio, Gabriel aplicó un ethos a partir de las narrativas de la entrega de dones a pueblos hermanos por parte de los muiscas. Gabriel atacaba a los líderes de PNMC por considerarlos "soberbios", pues "desconocían a sus abuelos" al afirmar que lo muisca solo necesitaba de lo muisca y no de otras etnias. Se refería también a que PNMC no reconocía, según él, la importancia del abuelo Víctor en la recomposición del pueblo muisca. Recordó las narrativas del "despertar" al afirmar que "el abuelo fue el primer anciano que después de cuatrocientos cincuenta años abrió las puertas de los espíritus muisca hace catorce años”. Rememoró además que los "abuelos ancestrales" habían entregado los "canastos" o "llaves de las bibliotecas espirituales muisca” a pueblos hermanos. 
Luego, su testimonio configuró un campo que no solo detallaba la historia contada y sus designios, sino que además marcaba claras relaciones de poder y legitimidad entre los muiscas y los líderes foráneos que, según Gabriel, "tenían guardado el conocimiento". Afirmaba que, para abrir las puertas de tales bibliotecas, había que pasar por tres puertas que a su vez correspondían con los dones entregados por etnias colaboradoras del "despertar", así: la puerta del yagé, representada en la medicina del taita Orlando Gaitán; la puerta del mambe y del ambil, representada en la del taita Víctor Martínez Taicoma, y la puerta de los poporos, representada en la medicina de los mamos de los grupos indígenas de la Sierra Nevada de Santa Marta. La arrogancia de PNMC, a la que él se refería, consistía en que sus líderes se creían "abuelos", cuando solo eran sabedores. Debido a que estas divisiones acentuaron las ya existentes entre PNMC y las comunidades muiscas oficiales, una red de prácticas espirituales, conformada por sus líderes de medicina, el taita Orlando Gaitán y unos mamos serranos —que incluiré más adelante-, nombró al abuelo Fernando Castillo, de la comunidad de Cota, como el "mayor de los muiscas". Por esa razón, según Gabriel, había que cuidar y proteger al abuelo, así como purificarse y limpiarse cada uno para ser recibido por él, para que así la devolución de llaves y puertas continuara. Por supuesto, considerar a uno u otro miembro de la red étnica como abuelo, sabedor o chyquy está determinado por el tipo de relaciones de alianzas, lealtades y colaboraciones que configuran sus propios ethos que buscan ser impuestos sobre otros. Estas figuras además corresponden a circunstancias históricas que enmarcan este tipo de relaciones y redes de intercambio y colaboración, pues vale decir que el mismo Gabriel en otras ocasiones reconoció como sus abuelos a José Pereira, de Cota, y a Sigifredo, Suaga Gua, de PNMC.

Tener una versión en la que cada participante de la red asume el papel de iniciador o de iniciado también configura relaciones simbólicas de poder. Por ejemplo, cuando le pregunté a Gabriel sobre la forma como había llegado alguna vez a pertenecer a PNMC, me dijo que lo había buscado el mismo Sigifredo, cuya versión es contraria cuando se le pregunta. Además, no dudan en deslegitimar mutuamente su trabajo espiritual, recordando elementos de su pasado; Sigifredo juzga 
a Gabriel por haber sido anarquista —y seguirlo siendo, según él—y en sentido contrario lo hace Gabriel, lo juzga por haber sido y seguir siendo "muy gnóstico" en su palabra muisca. El ethos aplicado por Gabriel para trazar esta relación conflictiva con Sigifredo llegó a un punto de inconmensurabilidad, que incluso afirmó que "estaba listo para morir". Por su parte, Sigifredo alimentaba la gramática de la violencia cuando me decía que si se metían con él, "podía pegar muy fuerte". Aquí nuevamente emergían los fantasmas de las batallas oníricas y del campo mágico.

Las versiones de Gabriel y Sigifredo sobre la enfermedad de la maloca pueden representarse mediante dos gráficas en las que vemos los respectivos actores del conflicto en este nodo principal (figuras 3 y 4). Más allá de establecer quién dice la verdad, cuestión que es irrelevante en mi estudio, lo clave es que las gráficas permiten identificar cómo se lee cada uno de ellos en medio del tejido conflictivo. Como indicadores relevantes, hay que anotar que ninguna de las partes desea mantener una buena relación con Ati Quigua por lo que su imagen de indigenista y "politiquera" representa para ambas, y que los nodos por los cuales se disputan relaciones armoniosas o no corresponden a los más importantes de acuerdo a la ética de los dones: el taita Víctor, el Jardín Botánico de Bogotá y sus receptores en competencia,

Figura 3. Versión de Gabriel respecto a la enfermedad de la maloca

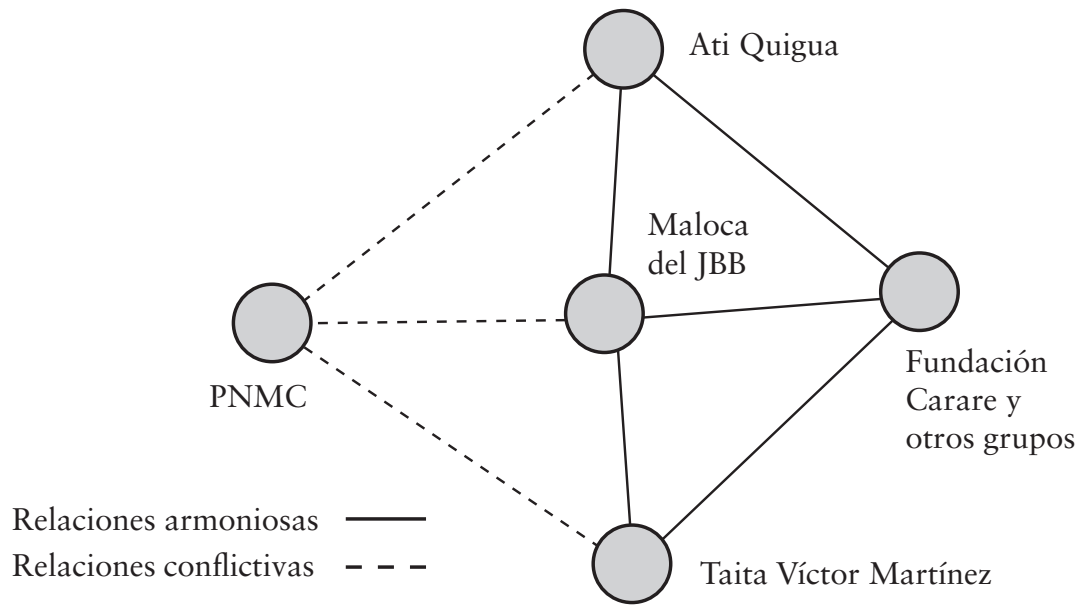

Fuente: Elaboración propia. 
Figura 4. Versión de Sigifredo respecto a la enfermedad de la maloca

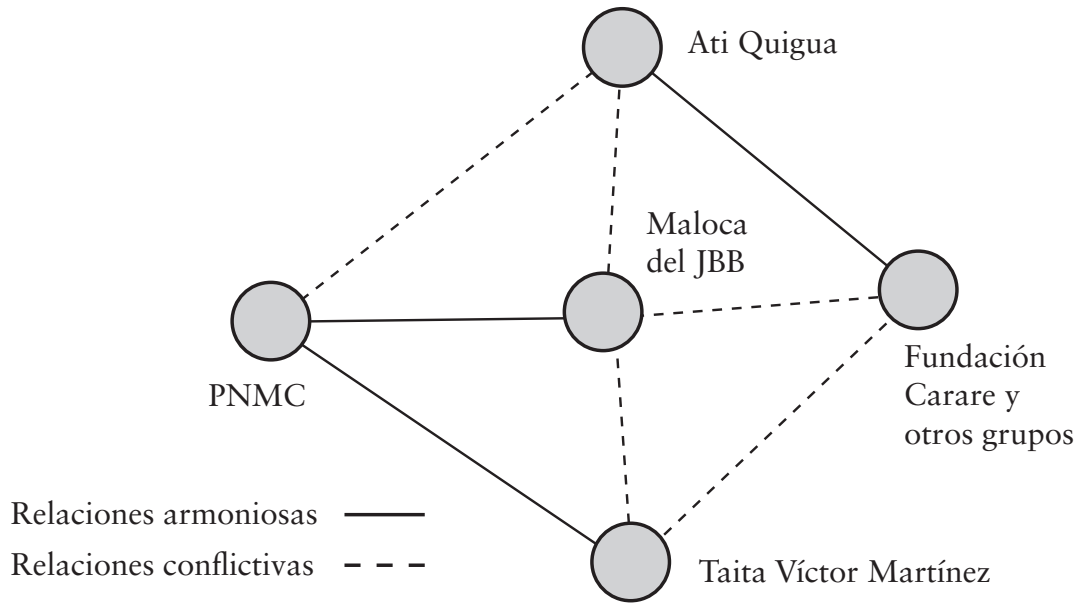

Fuente: Elaboración propia.

PNMC y Fundación Carare en conjunto con otros grupos y organizaciones indígenas.

Mientras estas disputas, muy masculinas por cierto, se desarrollaban entre egos y arrogancias, Janeth Yanguma, abuela de PNMC Bogotá, explica que las plantas por sí solas no traen el conocimiento ni las enseñanzas que forman la ética que buscan transmitir a quienes las usan y consumen.

Dentro de mi conocimiento y de lo que tengo claro es que tú puedes tener poporo, mambe, ambil, tabaco y toda una mochila llena de aseguranzas. Pero si tu pensamiento, tu sentir y tu hacer no es correcto, no tienes nada [enfatiza]. Y yo hablo esta palabra porque cuando estaba en maloca, cacique decía que si uno no sabía chupar verdaderamente y mambear, no era. Y yo decía: “¿Cómo es chupar?" Pues yo aprendí como era chupar. Chupar es verdaderamente chupar ambil y observar en mí qué soy, conocerme a mí mismo, cómo pienso, cómo siento y cómo actúo. Y hay dos ordenanzas que siempre recuerdo mucho. La primera es pensar, sentir y hacer. No hacer, sentir y pensar de último porque yo ya la he embarrado. La segunda: no hacer daño, no hacerse daño y no permitir que se haga daño. (Janeth Yanguma, 11 de mayo del 2012) 
Janeth Yanguma afirmó que la primera ordenanza la aprendió del taita Víctor, mientras que la segunda fue desarrollada por Sigifredo, la cual tuvo tanto eco que incluso fue consignada por la Fundación Carare en una cartilla que publicó sobre la relación entre la medicina y la resolución de conflictos, según me contó Rodrigo Niño, hermano de Sigifredo. Esto obedeció a que en un inicio hubo relaciones cordiales entre el taita Orlando Gaitán y PNMC; fueron varios círculos de palabra en la maloca en los que ambas organizaciones compartieron dichas palabras y principios morales, pero ahora Sigifredo lo toma como una "copia" de su palabra y le parece que es un acto contradictorio por parte de la fundación, pues esta lo juzga moralmente.

Con todo lo anterior, vemos que paralelamente a la conformación de discursos y metodologías de curación y limpieza relacionados con preceptos morales esos mismos discursos y metodologías configuraron ethos como sustratos de conflictos. Es decir, la intención terapéutica y curativa de los círculos de palabra también impulsó percepciones y conflictos a partir de su propia ambivalencia, la cual consiste en que toda limpieza parte de una suciedad; y toda curación, de una enfermedad. En este sentido, la superación de la suciedad o la enfermedad podría ser interpretada positiva o negativamente. Myriam Martínez Triviño, exgobernadora del Cabildo Muisca de Suba, siempre me insistió en que no compartía el hecho de que a los círculos de palabra de PNMC fueran jóvenes con problemas de alcohol y drogas, porque esto hacía que la gente interpretara la medicina indígena como un espacio psicodélico y de simple exploración de formas de "trabarse". Janeth Yanguma, por su parte, argumenta en favor de ello, recalcando que precisamente el trabajo de las medicinas es curar y sanar:

Ahora, cómo voy yo a curar si, por decir algo, tú vas a buscar indígenas y tú eres un borracho, por decir algo, y tú te curas en los círculos de palabra porque ese es el objetivo. ¿Entonces voy a invitar a los que están enfermos o a los que están bien? Y no llegaron porque los llamamos nosotros, fue un llamado espiritual y ellos llegaron allá. Y algunos de los que estaban en desorden con su marihuana, con una cantidad de cosas, lograron sanar, hay mucha gente de esa aquí en Bacatá. (Janeth Yanguma, 11 de mayo del 2012) 
El abuelo Manuel Socha de Chía me comentaba en una ocasión que cuando él comenzó a ingresar al campo de prácticas de medicina indígena fue juzgado por muchas personas, pues había tenido problemas de alcohol en el pasado. Tampoco entendía cómo esas personas que lo juzgaban seguían resaltando dicho pasado cuando la idea, según él, era interpretar que ese hecho significaba un testimonio positivo de transformación. Este mismo abuelo me contó también que cuando una empleada murui del jardín botánico, seguidora del taita Víctor, le pidió su opinión sobre la forma como se venía manejando la maloca y los problemas generados en torno a ello, contestó que esta "debía ser tumbada y construida de nuevo". Los conflictos entre organizaciones en torno al uso y liderazgo de la maloca fueron alimentados por rumores, de parte y parte, sobre magia negra, psicodelia sin control, sincretismos esotéricos y neohippismo. A su vez, cada parte del conflicto hacía responsables a otras de la enfermedad que ello le causaba al abuelo Víctor. Pese a que la maloca terminó siendo demolida, el taita Víctor continuó trabajando directamente en los escenarios convocados por la Fundación Carare y los líderes de medicina de la comunidad muisca de Bosa, y PNMC tuvo que buscar otros espacios para realizar sus círculos de palabra. No obstante, esas diferencias que se hicieron evidentes en torno a la maloca continuaron trascendiendo a ámbitos políticos e institucionales. En junio de 2012, cuando me encontraba en una conferencia de la profesora Joanne Rappaport, en el Jardín Botánico de Bogotá, una profesora y amiga, Mónica Espinosa, me dijo que se había enterado, por otra asistente a la conferencia, que cuando demolieron la maloca encontraron varios "entierros" y elementos relacionados con campos mágicos y esotéricos, que unas personas buscan poner en diálogo con la medicina indígena, mientras que otras los rechazan y condenan.

\section{El Templo del Sol de Sogamoso: poporos y otros dones del Corazón del Mundo}

Son casi las diez de la noche del día 20 de diciembre del 2010 en Sogamoso, municipio del departamento de Boyacá, Colombia. La constelación de Orión, alineada con Venus o Fagua ('lucero de la mañana', 
según los muiscas), se impone en el cenit sobre la punta cónica del techo del templo. La luna llena, eclipsada, ilumina el camino hacia el costado occidental del templo, pero la entrada está cerrada. Los asistentes —entre estos, miembros de cabildos contemporáneos muiscas, seguidores del taita Orlando Gaitán de la Fundación Carare, grupos musicales con zampoñas y tambores, y uno que otro turista neohippie- se descalzan y, en fila, comienzan a danzar mientras avanzan zigzagueando los doce postes que enmarcan el costado sur del templo. La danza avanza solo media circunferencia hasta la entrada del costado oriental. Quien llega hasta ahí se pone de espaldas y entra al templo. El fique o guaque quemado sobre barbacoas aromatiza el lugar. Sobre la coronilla, un miembro de una fundación de tomadores de yagé aspira la cabeza de cada asistente. Luego, en un camino formado por dos filas paralelas, los guairas o yageceros de cierto nivel y con una función determinada dentro de dicha fundación sacuden ramas sobre los cuerpos que tienen en frente. A continuación, Xieguazinsa, gobernador del recientemente posesionado Cabildo Muisca de Chunza (Tunja), le asigna a cada participante un joven de comunidades muiscas presentes para que soplen algo de humo de tabaco sobre sus extremidades, pelvis y espalda. La mayoría de estos jóvenes pertenecen a la comunidad de Bosa. Algunos tybas o jóvenes de mediana jerarquía del Cabildo Muisca de Bacatá (Bogotá) de PNMC tocan sus tambores y entonan cánticos de guerreros o güechas. Quienes fueron limpiados con tabaco se integran a una danza circular que rodea el poste central del templo. Cada participante debe darle la vuelta tres veces y, antes de salir del recinto por la puerta occidental, son ungidas sus muñecas con una loción por otros miembros de la Fundación Carare.

El popurrí de imágenes, prácticas y organizaciones presentes en esta ceremonia indican que la celebración de la Fiesta del Huan o Zocam que se llevó a cabo aquella noche del 20 de diciembre del 2010 es un objeto-red conformado por múltiples incidencias. La primera consiste en que el Templo del Sol del Museo Arqueológico de Sogamoso, lugar donde se desarrolló, es considerado una réplica del mítico templo del sacerdote Suamox, elaborada por el reconocido antropólogo boyacense Eliécer Silva Celis, con base en sus excavaciones arqueológicas y referencias etnohistóricas (Silva, 2000). Para la familia del antropólogo, 
este templo es un legado patrimonial para la humanidad y, para los muiscas, representa un don devuelto. Sin embargo, las disputas por tener el papel legítimo de herederos de dicho patrimonio evidencian uno de los principales conflictos entre la oficialidad y la institucionalidad del museo y los repertorios de una memoria alternativa muisca. Ahora, de otro lado, que una u otra organización indígena de la red étnica estudiada asuma el liderazgo de esta fiesta es un hecho que configura conflictos en torno a la representatividad y la legítima autoridad. A este último campo de conflictos se le suma la devolución de dones como el yagé y el poporo a los muiscas por parte de taitas y mamos. Con base en este panorama de conflictos que de manera sucinta mencioné, el objetivo de los siguientes apartados es trazar los mapas de la inconmensurabilidad que se gestan en estos marcos etnopolíticos, así como las propuestas de mediación y resolución de conflictos. De la misma manera como desarrollé los asuntos atinentes a la maloca del taita Víctor, las incidencias que configuran el Templo del Sol en cuanto objeto-red se trazan a partir de los itinerarios, prácticas y narrativas de varios líderes y miembros de la red.

\section{Rodrigo Niño y Orlando Gaitán: disputas por el liderazgo del Zocam}

Rodrigo, Xieguazinsa, me contó que aunque llevaba más de veinte años trabajando como líder muisca de Boyacá, nunca había asistido al Templo del Sol, sino hasta el 2007; "siempre dije que iría cuando el dueño de casa me invitara”, afirmó Rodrigo. Y todo comenzó con la muerte del profesor Silva Celis ese mismo año, quien pese a que nunca había tenido en vida ningún contacto con estas comunidades muiscas emergentes, varios de sus líderes lo consideraban un abuelo mayor y sabedor. Era considerado un muisca que de manera implícita hacía un trabajo de gran importancia espiritual a través de su labor como académico e investigador. Su funeral se celebró en el mismo Templo del Sol. Rodrigo, al enterarse de su muerte y exequias, llegó al templo acompañado de varios integrantes de su comunidad. Los inesperados visitantes, que llevaban vestiduras blancas, collares de cuentas, sonajeros y maracas, irrumpieron con cánticos entonados en una lengua 
muisca recuperada. Compleja debió ser la reacción de Margarita Silva, hija del profesor y directora del Museo Arqueológico de Sogamoso, que en medio de la tristeza y la sorpresa veía cómo Rodrigo depositaba tabaco y hayo (hojas de coca) sobre el féretro del difunto. Esa fue la primera vez que Rodrigo tuvo contacto con el "dueño de la casa".

$\mathrm{Al}$ año siguiente, en un encuentro académico en la UPTC, Sede Tunja, Rodrigo se presentó nuevamente ante Margarita. Ella lo reconoció y más adelante lo invitó a formar parte de la Mesa del Huan, un grupo interdisciplinario constituido por académicos y promotores culturales, encargados de planear y administrar la celebración oficial del solsticio de diciembre en el Templo del Sol. Durante varios años, el templo se convirtió en un escenario donde grupos teatrales infantiles de colegios representaban danzas, mitos y rituales muiscas, basándose en las narrativas y estéticas del currículo oficial escolar. Desde el 2007, cuando Rodrigo participó por primera vez en esta celebración, la Fiesta del Huan o Zocam se convirtió en una miscelánea performativa de diferentes comunidades, en la que los participantes acampan desde el 19 de diciembre en los terrenos del parque Conchucua, al lado del museo y del templo, y participan en la ceremonia principal para recibir al Sol. Con esa transformación de la rutina y la parafernalia de la fiesta se instauró una naciente tradición, a la cual eran invitados líderes espirituales de otras etnias del país para que dirigieran los rituales.

Cuando Rodrigo se encontró con Margarita en aquel evento académico también conoció al taita Orlando Gaitán, quien un año atrás había organizado una toma masiva de yagé en el templo, ocasión en la que había congregado a más de seiscientas personas gracias a contactos establecidos con un médico de la región. Según Rodrigo, el taita se ganó aún más la confianza de Margarita al haber curado a una de sus hijas, Ximena, quien lideraba en ese entonces la fundación que lleva el nombre de su abuelo. El taita Orlando Gaitán y esta fundación ya lideraban espacios de curación en la maloca del jardín botánico y habían logrado constituirse como una EPs de medicina indígena. Según varios testimonios, el taita se había convertido prácticamente en el médico de la comunidad muisca de Bosa y, como se resaltó en apartados anteriores, varios que habían transitado por PNMC llegaron a tomar yagé con él y a integrar la "comunidad Carare", denominada así por 
ellos mismos. Su experiencia en asuntos políticos y conocimientos en negociaciones y resoluciones de conflictos lo llevaron a ser un mediador entre los líderes de PNMC y los de las comunidades oficiales. La idea que trascendía tales conflictos era lograr la unión del pueblo muisca. En la versión de la Fiesta del Zocam de ese año, 2008, se acordó que se realizarían tres congresos del pueblo muisca con el fin de lograr superar los conflictos internos y que la comunidad encargada del primero sería la de Bosa. Pero al igual que la historia de las certificaciones de Sigifredo como autoridad espiritual de Suba y Cota, los acuerdos de los líderes de Bosa atinentes a la solución de los conflictos fueron invalidados por otros miembros de esta misma comunidad. Cuando le pregunté a la lideresa Victoria Neuta por qué nunca se habían llevado a cabo los congresos pactados, me dijo que ella y varias personas se opusieron a estos y así invalidaron los acuerdos de sus representantes. Esto demuestra que en cada parte del conflicto hay facciones más radicales que otras. Además, Victoria, en el marco de un encuentro académico con presencia de varios líderes muiscas y de PNMC, advirtió que "de ninguna manera" un encuentro como ese se podía llegar a considerar un "acuerdo". Para ella, eso era lo que había ocurrido en el Templo del Sol, en el 2008: nunca hubo ningún acuerdo oficial, o por lo menos uno que involucrara de manera más general a las comunidades, y no solo a los pocos representantes de la práctica medicinal y espiritual.

Respecto al taita Orlando Gaitán, su carisma, sus conocimientos de yagecero y la capacidad de gestión de su fundación lo consolidaron como auspiciador imprescindible de la Fiesta del Zocam, pues había logrado patrocinar el viaje de los líderes indígenas que dirigían cada año los rituales de sanación del solsticio. Esos capitales simbólicos hicieron que el liderazgo de la Fundación Carare se impusiera sobre el de cualquier comunidad muisca. Esto quedó demostrado en la forma como se realizó el performance de una comparsa por las calles de Sogamoso que participó en la celebración del Zocam, en la noche previa al solsticio. Según los cronistas, el performance también representó una manera de renovar una antigua versión de esta fiesta, aunque con cierta inversión de papeles. 
François Correa Rubio (2004), en esta obra referente a la simbología y política de los muiscas en el momento de la llegada de los españoles, presenta dos versiones de la fiesta en cuestión. Una la reconstruye a partir de las crónicas de Piedrahita, cuyo protagonista es el cacique de Ubaque. En esta versión, los móviles de la fiesta eran la iniciación a los herederos del cacicazgo y la solicitud, mediante "plegarias" al Sol, para que hubiera buena cosecha y evitar la enfermedad y la muerte. Por eso, la antigua Fiesta del Huan en Ubaque se realizaba en diciembre, al comienzo de las cosechas, y dentro de su parafernalia era muy representativo el papel de la tristeza. Según Piedrahita, los participantes desfilaban y se presentaba un doble juego en la fila: mientras que los de adelante suplicaban mediante el llanto peticiones al Sol, los de atrás daban grandes saltos y expresaban risotadas de alegría porque el Sol les había cumplido lo añorado por los delanteros (Correa Rubio, 2004, p. 106). Y al parecer, la celebración convocaba a varias parcialidades, y con ello, entre tanta diversidad de culturas territoriales y de jerarquías políticas y sociales, el cronista percibió un popurrí. En palabras del propio autor:

Lo más notable es que el cronista distingue el orden del desplazamiento de las gentes según su rango, las actividades que realizaban y su indumentaria: cada parcialidad, por sus pieles de animales; los sacerdotes, por su mitras; los danzantes, por sus cuerpos pintados y máscaras de llanto; los que barrían el camino, por sus mantas y máscaras de oro, y los caciques y acompañantes, por los lujosos atuendos que los diferenciaban entre sí pero los relacionaban con sus parcialidades. (Correa Rubio, 2004, p. 107. Énfasis del original)

Nótese el énfasis que Correa Rubio hace en la diferenciación de las "parcialidades" o comunidades que asistían a este encuentro. De igual forma, la fiesta de hoy en día convoca una heterogeneidad de comunidades, organizaciones y grupos, que entre todos tejen una red de imágenes, cuerpos, colores, cánticos e indumentarias, cuya performancia resalta la representación romántica y exótica de lo indígena, a la vez que lo silencia en otros niveles. El abigarramiento de ruanas, batas, penachos con plumas, gorros de lana, collares e instrumentos musicales era de tal magnitud, que incluso el fotógrafo que me acompañó en el 
trabajo de campo más de una vez me preguntó “quiénes eran los muiscas" entre todas esas personas. El desfile de aquella noche del 20 de diciembre del 2010, tal vez tratando de recrear el esquizofrénico ritual de risa y llanto de antaño, consistía en un gran bloque caminante dividido en varias "parcialidades" a su manera. La apertura de la comparsa estaba a cargo de dos mujeres de la comunidad muisca que sostenían banderas de colores y un pendón con el logotipo de PNMC, que invitaba al "autorreconocimiento" étnico: "Póngase Muisca”, se leía en este. Detrás de ellas, pero evidentemente en una posición privilegiada, estaban Rodrigo Niño, chyquy muisca, y Orlando Gaitán, taita líder de la Fundación Carare, auspiciadora del evento oficial, llevando un fotuto el primero y un tambor el segundo; ambos comandaban la marcha y la música. Los seguían varios mamos arhuacos, koguis y kankuamos de la Sierra Nevada de Santa Marta, quienes eran las autoridades espirituales invitadas ese año a dirigir el ritual mayor. A esta comisión de apertura le seguía una escuadra de guairas y tocadores de tambor y sonajeros, quienes marcaban las jerarquías de la Fundación Carare. La reverencia extática al taita Orlando y el paroxismo que causaba hizo que su séquito se apropiara de la comparsa, mientras que los tybas muiscas, que iban inmediatamente detrás, con sus tambores y maracas, procuraban unirse al compás liderado por aquellos. A diferencia de la versión del cronista Piedrahita, el "cacique" desfilaba adelante, y a medida que los integrantes de la marcha se ubicaban más atrás, parecían quedar excluidos; los de la risa, esta vez, fueron los de adelante.

El Zocam del 2010, según las autoridades espirituales convocantes, era de limpieza y de sanación espiritual. Sin embargo, el propósito inicial de Rodrigo y de los mamos era que los líderes y las personas de más jerarquía de las comunidades muiscas presentes se quedaran dentro del Templo del Sol para esperar la entrada de la luz del astro por las ventanas orientales. Pero la orden de Margarita Silva, directora del museo, fue tajante: nadie debía permanecer en el templo y todos tendrían que esperar el amanecer afuera. Su decisión fue categórica al ver que un joven miembro de PNMC, Augusto Tiguasusa, ingresó al templo con un séquito de tocadores de tambor y entonaron cánticos que rompieron el silencio y la tranquilidad del templo. Para Rodrigo, el error de Tiguasusa fue creer que en el templo era permitido celebrar 
rituales con cantos guerreros cuando solo se podían celebrar aquellos de recogimiento y reflexión. Estas diferencias también generaron más adelante la salida de Tiguasusa de PNMC y la conformación de otra comunidad muisca alternativa. Lo cierto es que la institucionalidad dejó muy claro quién administraba oficialmente aquel patrimonio.

\section{Mamos y muiscas: entre la hermandad y la mímesis}

Las fronteras simbólicas que se establecieron durante la comparsa descrita anteriormente estaban relacionadas con los conflictos que los líderes indígenas del Zocam se proponían agenciar. La versión de la fiesta de ese año tenía como propósito establecer acuerdos que propendieran a la solución de las disputas entre las organizaciones muiscas, particularmente entre PNMC y los líderes de medicina de las comunidades oficiales. A su vez, la presencia de varios mamos o autoridades espirituales de los grupos indígenas ika, kággaba, wiwa y kaukamo señalaba la importancia de su papel en el "despertar muisca" en cuatro aspectos: devolver las herramientas muiscas que estaban guardadas en la Sierra Nevada de Santa Marta, acompañar los procesos de recomposición cultural muisca, actuar como mediadores de sus conflictos y consolidarse como parte de los "verdaderos" mayores de estas comunidades.

Antes de que iniciara oficialmente la Fiesta del Huan o Zocam, varios líderes muiscas y de otros grupos indígenas se reunieron la noche del 19 de diciembre del 2010 en un círculo de palabra en torno al fuego. Enrique, mamo de la comunidad kankuama, dio inicio a la palabra en el círculo:

Hermanos, queremos escuchar... que nos digan algo los que quieran hablar... queremos escuchar sus palabras ... aquí no nos vamos a poner que yo sé más, que yo soy esto... no, aquí todos somos hijos de nuestra Madre Tierra [emite sonido de aprobación: mmjij]... el sol ilumina a todos, la luz nos va a dar luz a todos... bebemos agua, la misma agua... entonces yo quisiera que nos sentáramos, que juntáramos la palabra, el que tenga mambe come mambe, y el que tenga su hayo se mete su hayo, vamos a masticar la palabra, 
estamos aquí en la palabra dulce de amor... hay una chicha que se va a dar alrededor que es la que endulza más la palabra ${ }^{74}$. (Mamo Enrique, 19 de diciembre del 2010)

Curiosamente, y a diferencia de la disposición espacial que he registrado en otros espacios de conversación indígena, el fuego no se encontraba en el centro del círculo de palabra. El mamo Enrique dio a entender que el fuego estaba ubicado hacia la salida de la carpa que nos albergaba para que las "cosas malas fueran allá y se quemaran”. Los días previos a la fiesta se reservaban para generar varios espacios de diálogo y debate sobre la unión del pueblo muisca con la mediación y acompañamiento de líderes espirituales de otros grupos étnicos. El mamo Enrique culminó su discurso de apertura del círculo de palabra, diciendo:

Yo creo que estamos como hermanos indígenas. A mí no me gusta que me digan indio porque yo no soy indio, yo soy indígena, étnico... pero como los españoles nos trataron fue de indios ladinos... a mí no me gusta...

Hoy estamos es un solo pueblo unido aquí, hoy está el Templo del Sol como el Corazón del Mundo... entonces yo pienso que vamos a darle fuerza... estos acuerdos que se empezaron a dar [...] viendo que hay que hacer acuerdo entre nuestro territorio... el territorio kankuamo son doce comunidades y ahí, de esas doce comunidades, también hay desacuerdos y todo se hace así y todo se lleva a un solo, a una sola palabra... yo creo que esta noche los muisca de Bosa, de Suba, Sesquilé, Cota, Chía, Sogamoso, vamos a respetar esa palabra...

Decía el hermano [señala a Rodrigo, Xieguazinsa] que de pronto no era el tiempo, pero la Madre permitió que este fuera el tiempo, dijo que nos reuniéramos todos a compartir y coger un año nuevo con un pensamiento nuevo... y así unidos tenemos que recoger

74 La chicha a la que se refería el mamo era la caguana, bebida tradicional de los pueblos amazónicos preparada con zumo de piña, almidón de yuca y panela. 
fruto-ofrenda $[$ sic $]$ para llevarlo allá a esos sitios... (Mamo Enrique, 19 de diciembre de 2010)

La palabra del mamo parecía ser una simple invitación al diálogo y al acuerdo, pero si la analizamos, podemos desamarrar una urdimbre de incidencias. El mamo Enrique comienza afirmando la hermandad indígena e inmediatamente después establece una frontera discursiva entre las palabras indio e indígena. Una constante de los procesos de reivindicación de la memoria indígena es la crítica a la clasificación a partir de categorías coloniales. La palabra indio se extendió a raíz de la confusión de Cristóbal Colón, pues creyó haber llegado al otro lado de la India. Pero lo importante aquí es resaltar que la misma categoría de indígena o étnico — palabra que el mamo Enrique yuxtapone a la primera - es una identidad colonial igualmente homogeneizadora usada en la actualidad para denotar a un grupo de sujetos que apelan a un lazo de fraternidad. Dichos vínculos crean una comunidad de sentido, construyendo una memoria común basada en una historia que narra cómo una cultura indígena, vista a sí misma como víctima gallarda, vivió los procesos de sumisión, asimilación, resistencia y reivindicación ante la invasión del hombre blanco.

Esta tendencia, generalizada en la actualidad, crea un panindianismo que parece, en ciertas ocasiones, tomar la forma de lo que Victor Turner denominó “communitas”. La communitas se caracteriza por ser un modo de establecer relaciones sociales que crean sentido de comunidad, atribuyéndose lo que tradicionalmente pertenece al débil (1969, p. 119). Para Turner, la communitas surge donde no hay estructura social, emerge cuando se concibe que la comunidad no la define el estar "junto al otro", sino "con” el otro, pero bajo las condiciones de liminalidad, marginalidad e inferioridad (1969, p. 134). De ahí que sea coherente, en el caso de una communitas basada en la categoría unificadora de "lo indígena", su autovictimización para legitimar su presente, mediante la consigna de reivindicarse y enorgullecerse por incidencias trágicas del pasado. A esto lo denominé la "memoria del conflicto", en un estudio anterior (Gómez Montañez, 2013a), y en esta 
ocasión sugiero que su reactivación emotiva aporta a la conformación de una "comunidad del sufrimiento" 75 .

De esta manera, no en vano, el mamo Enrique "recuerda" al auditorio que fueron tratados como ladinos por parte de los españoles. Según los relatos de varios muiscas, con la llegada de los españoles, los nativos en general se dividieron en dos: los ladinos y los chontales ${ }^{76}$. El ladino fue el indígena que se doblegó ante el blanco, asumiendo su religión y costumbres. El chontal, en cambio, es presentado como el indígena heroico que enfrentó y resistió al europeo, y para salvar el legado ancestral de su pueblo, en algunos casos huyó a tierras altas, así logró conservar sus usos y costumbres en medio de los cambios sociales y culturales de la época. El término ladino además suelen usarlo los chyquys de PNMC para referirse a la persona que mantiene "dormida" su memoria indígena ${ }^{77}$.

En el caso muisca, esa gallardía es la que pretende legitimar su existencia en el presente pese a que, para varios sectores de la sociedad en general, el muisca no sea más que una invención o una imagen del pasado indígena de Colombia, un idealismo sin bases reales de existencia y reproducción actual o un aspecto residual contenido en un evidente mestizaje en sectores campesinos y obreros del altiplano cundiboyacense. Por consiguiente, es normal que la visibilización y puesta en escena de grupos autodenominados muiscas que tienen repertorios y rutinas relacionadas con aspectos rituales y estéticos (vestuario, accesorios, uso de herramientas como el tabaco, el poporo, la mochila y otras) se tome como un ejercicio netamente mimético. Sin embargo, a partir de

75 Tomo este concepto del caso del ritual del Isoma, documentado por Victor Turner. En este, por ejemplo, las personas que han pasado por un proceso de enfermedad pueden ayudar a otras que estén en la misma situación, así no exista ningún lazo de parentesco entre estas. El sufrimiento, entonces, es el elemento cohesionador en este tipo de communitas.

76 Véase el apartado "La danza del cóndor y el águila: narrativas del 'despertar muisca”" del tercer capítulo.

77 Paul Ricouer propuso los conceptos griegos de mneme y anamnesis para diferenciar el recuerdo "que aparece" del recuerdo "que es activamente buscado" (2000, pp. 19-20). Retomo esta relación más adelante. 
la interpretación, algo mesiánica, de la devolución de dones por parte de etnias hermanas a los muiscas, se produce una continuidad tanto moral como coherente con el pasado fundamentada en una memoria más simbólica que basada en datos históricos verificables.

Como lo he demostrado, durante mi trabajo de campo registré la conformación de una red de mamos y líderes espirituales y de medicina muiscas. Los relatos de varios de sus protagonistas coinciden en que algunos estaban "escuchando los cánticos de los muiscas en la Sierra Nevada de Santa Marta" y que dicha conexión de tipo espiritual dio paso a una serie de encuentros entre ambas culturas; fueron muchos los mamos que viajaron a Bogotá en busca de quienes cantaron y asimismo muchos los líderes muiscas que los visitaron en su territorio. De esta memoria imaginada pueden desprenderse algunos elementos que evidencian los principios histórico-transaccional y de anclaje, fórmulas propuestas para este estudio y mediante las cuales se pueden comprender las relaciones legítimas con el pasado y las coherencias con el presente elaboradas discursivamente en el campo etnopolítico muisca.

En primera medida, el modelo de red enmarcado en un conjunto de transacciones energéticas de tipo espiritual corresponde a una figura que sustenta en el presente la tendencia de los grupos indígenas latinoamericanos de hablar de una gran unión amerindia que debe despertar al espíritu ancestral para recuperar el equilibrio cósmico que se perdió, por supuesto, desde la conquista de América. En segunda medida, la relación mamos-muiscas trasciende el argumento de la pertenencia común a la macrofamilia lingüística chibcha y apela más a una hermandad de carácter cósmico y espiritual. En tercera medida, la memoria reciente de la búsqueda mutua y el contacto entre mamos y muiscas ha conformado una serie de relatos y versiones de dicha relación interétnica donde cada interlocutor busca otorgarse un papel que legitime su inclusión como parte y nodo de tan importante red de intercambios. De igual forma hace ver a los líderes espirituales y de medicina muiscas como legítimos y originales portadores de los dones devueltos, y no como simples imitadores de los mamos. Como veremos más adelante, las fronteras entre la imitación —que significa someterse a quien considero es mi modelo a seguir- y la originalidad — que 
significa que yo soy el modelo a seguir - van a marcar campos de conflictos de poder simbólico en dos planos. Por un lado, el de las disputas entre los mismos líderes de la amplia y variada red étnica muisca por sus papeles de legítimos receptores de los dones y de la palabra medicinal de los mamos, caso similar al estudiado respecto al taita Víctor y sus redes de iniciados. Por otro, la manera en que cada líder traza límites entre la autoridad e influencia de los mamos y la suya propia. Ambos planos se cruzan y aparecerán a medida que vaya explicando los dones devueltos por los mamos y sus implicaciones en la construcción de nuevos ethos de la espiritualidad muisca.

\section{Pagamentos: culpas, expiaciones e integración de dones}

Retomando el discurso del mamo Enrique - transcrito páginas atrás-, quiero señalar que él afirma que "el Templo del Sol es el Corazón del Mundo". Precisamente, con este sintagma nomimal estilístico se conoce, por antonomasia, a la Sierra Nevada de Santa Marta o Gonawindwa, que representa el axis mundi de los grupos indígenas de ese territorio. Además, sus palabras dejan claro que, como líderes espirituales de otros grupos, desean que haya un "trato", un "acuerdo", que dé solución a los conflictos y que contribuya al despertar de la memoria muisca. Para ello, los mamos han enseñado varios principios éticos que se relacionan con métodos de sacrificio y pago a la Madre Tierra para curar a las personas. En este caso la misma Madre Tierra es quien ha entregado sus dones y el compromiso moral de sus hijos es pagarlos y devolverlos. Por esta razón, y en la medida en que los muiscas han incorporado este principio de comunión con los dioses, propongo que el intercambio de dones, unido al esquema sacrificial de ciertas prácticas rituales, conforman la base sobre la cual se fundamenta la existencia del "despertar muisca" en la actualidad, en el marco de las redes étnicas de la espiritualidad y la medicina. De esta manera, el sistema de "dar, recibir y devolver" que tomé de Mauss se integra a lo que propongo entender como un flujo de transacciones energéticas que opera en dos ejes. Por un lado, entre la persona que está en el ritual y el mundo espiritual, eje en el que prima la necesidad de la curación y la expiación. 
Por otro, un eje que hace posibles las relaciones intergrupales y de comunión. Del cruce entre un eje vertical (hombres-abuelos espirituales) y otro horizontal (relaciones personales y grupales) emergen las formas del "despertar".

Los muiscas han integrado las enseñanzas y los dones devueltos por el Amazonas y la Sierra Nevada de Santa Marta. De esta manera las rutinas curativas y reflexivas del mambeo y del ambil, además de las compartidas por los mamos, han conformado un cuerpo de prácticas y discursos que se denominan genéricamente "confiesos" y "pagamentos". El confieso - me lo explicaba Janeth Yanguma, a partir de lo que aprendió del taita Víctor en la maloca- significa "limpiar el pensamiento" y "sentir"; a veces los sabedores y abuelos son el puente para que los padres creadores reciban lo que la persona está limpiando y sintiendo, es un ejercicio de comunión directa con los dioses, y por eso, podría entenderse como una expresión de la memoria mística ${ }^{78}$. Respecto al pagamento, el cual sugirió el mamo Enrique como medio de limpieza para llegar a acuerdos, la Madre Tierra contiene la memoria ancestral de todo indígena y debe ser activada por cualquier persona que busca su "despertar". Por cierto, sobre la categoría del "recuerdo" es importante traer a colación la idea que, desde la fenomenología de la memoria, Paul Ricoeur elabora al proponer la transición de la pregunta centrada en "el sujeto que recuerda" hacia "lo que se recuerda". Con respecto a lo último, nos invita a pensar en la doble dimensión de la memoria desde las concepciones griegas de mneme y anamnesis. La primera es el recuerdo que aparece como algo pasivo y súbito con alguna carga de pathos - aunque es una noción polisémica, en este contexto denota la enfermedad, la pasión, el sufrimiento patológico y nos aporta elementos reflexivos para entender la relación entre memoria, trauma y violencia-. La segunda es un recuerdo que es activado, buscado, y está relacionado con las dinámicas que introducen versiones del pasado (Ricoeur, 2000, pp. 19-20). Las prácticas del confieso y del pagamento, por su carga patológica y altamente reflexiva, activan

78 Noción explicada en el apartado "Memoria mística y dogmática" del tercer capítulo. 
lo que los muiscas denominan su "memoria ancestral”, basándose en ambas clases de recordación.

A propósito de la integración de los ethos a través de la palabra del taita y la de los mamos, quiero mostrar cómo algunas rutinas paralelas al uso del tabaco y del algodón pueden ser comprendidas por medio del esquema sacrificial propuesto por Hubert y Mauss (1970). En este caso, ambos dones se convierten en víctimas sacrificiales que muestran que la primera condición del "despertar muisca" es la expiación de las culpas del ladino. Mediante el uso del tabaco y el algodón, el sacrificador-oferente busca su propio linaje espiritual que se encuentra resguardado en el cosmos y dentro de la Madre Tierra y permite que los “abuelos le hablen al oído". Desde esta mirada, volviendo a la reflexión de Ricoeur, se puede decir que el "despertar muisca" es un ejercicio colectivo que activa la imaginación ${ }^{79}$.

El tabaco sirve para consagrar cualquier elemento ritual y, a la vez, como víctima o don entregado a los abuelos espirituales. En su forma de cigarro, se sopla, se le habla, se ofrece a los padres mayores, a los abuelos ancestrales del linaje y a los abuelos del territorio. Las primeras expulsiones de humo se interpretan como alimento de los abuelos, las siguientes sirven para limpiar las vías respiratorias y para "limpiar el cuerpo y el espíritu”. Cuando se toma con la mano izquierda y se rota durante la chuma (sensación de borrachera y náuseas que produce), el tabaco recibe toda la carga negativa de su consumidor, en cambio, con la mano derecha, es para pedir y recibir dones de los abuelos espirituales. Entonces, sin detenernos en la ambivalencia del papel de esta planta, podemos ver que el cigarro de tabaco es una víctima expiatoria y piacular (porque limpia y cura), así como un don ofrecido a los abuelos para recibir algún favor.

La línea divisoria entre sacrificio y purificación puede desaparecer en la práctica descrita anteriormente, pero la ambigüedad y la ambivalencia de este modelo sacrificial-curativo aparecen cuando el consumo

79 En este punto del análisis podemos traer a colación la relación que el mismo Ricoeur explora entre la memoria y la imaginación, en la cual toda imagen, en cuanto "representación de la cosa ausente", es un índice de lo que ya pasó. De ahí que recordar sea, de alguna manera, imaginar. 
de tabaco acompaña el sacrificio de otras víctimas ${ }^{80}$. Es el caso de cierto modelo de pagamento enseñado por mamos ika a la comunidad de PNMC, en el año 2008. Antes de continuar, es necesario aclarar que el vínculo entre los seres humanos y la Madre Tierra se interpreta bajo la forma de un "tejido" (Gómez Montañez, 2010). Por esa razón, uno de los elementos que algunos mamos y chyquys cargan en su mochila es algodón o fibras vegetales parecidas a la pelusa del fique; esa fibra representa el hilo que une al sacrificante con los abuelos espirituales. La persona divide en dos su porción; una queda en su mano derecha; y otra, en la izquierda. Al igual que el manejo de la lateralidad del tabaco, primero se maneja una limpia con la izquierda. A medida que el sacrificante del algodón lo manipula, ambos se ungen y transfieren energéticamente su esencia. El pedazo de algodón se convierte en la parte del hombre que debe morir. De esta manera, la persona rota su mano izquierda, cierra los ojos y mientras piensa en todo aquello que desea limpiar y curar de sí mismo va enrollando con las yemas de sus dedos la fibra hasta formar un hilo o palito ${ }^{81}$. Se repite la misma rutina con el hilo de la mano derecha, pero en este momento ocurren dos cosas: primero, el oferente imagina varios dones dorados para que en una dimensión espiritual los abuelos los consuman: chozas de oro, alimentos de oro, lanzas de oro, totumas de oro, etc. Segundo, se les solicita a los abuelos los favores y dones buscados. Hasta acá la rutina parece ser de simple expiación-ofrenda. Pero ¿de qué manera deviene en sacrificio para que ambas intenciones se cumplan?

El mamo o líder de este pagamento recoge los hilos en orden (primero los de limpia o mano izquierda y luego los de ofrenda-favor de la

80 El tabaco acompaña casi todos los rituales muiscas. Menciono el ejemplo de la "entrega de placenta", descrito en Gómez Montañez (2009, pp. 111-113), ritual en el que la víctima-don es la placenta de la madre, la cual se entrega a la tierra y al cosmos mediante un entierro al lado de una laguna sagrada.

81 Aunque esta rutina busca en cierta manera una limpieza individual, deviene en colectiva por dos factores: por un lado, por lo general el chyquy habla en voz alta, mientras dirige y armoniza las enunciaciones individuales; por otro, el grupo se dispone en círculo y se invita a limpiar también los elementos colectivos como la familia, el linaje y el territorio. 
mano derecha). Separados en dos grupos, los algodones son guardados para ser enterrados o lapidados en algún lugar sagrado conocido únicamente por los mamos. A su vez, los sitios de pagamento configuran una red compleja de lugares conectados entre sí, en la cual la Madre Tierra es un gran complejo donde cada aspecto de la vida de las personas se paga. De esta manera se crea un cuerpo espiritual que puede conectar lagunas, montañas, rocas y otros mojones sagrados, armando así una cartografía (Santos y Mejía, 2010; Santos, Mejía y Candil, 2012). De acuerdo con las palabras del mamo Enrique, el Templo del Sol de Sogamoso estaba conectado espiritualmente con la Sierra Goanawindwa. Gracias a esta conexión, los mamos hacen presencia en territorio muisca para despertar su memoria y su espíritu. Pero tal intento de armonización y comunión también despertó malestar, violencias simbólicas y enfermedades.

\section{Poporos y tejido: entre el "despertar", el desorden y la enfermedad}

Varios mamos llegaron al centro del país y establecieron múltiples relaciones y alianzas con numerosos líderes y comunidades. Ati Quigua, dentro de su andamiaje indigenista y político, contaba con algunos mamos en su equipo asesor, el mismo que acompañó el proyecto por la defensa de las fuentes hídricas de Bogotá y su campaña política "Todos ATIerra". Otros mamos participaron en los primeros procesos de resignificación de lugares sagrados de Bogotá y Cundinamarca y establecieron vínculos fuertes con Carlos Mamanché y la comunidad muisca de Sesquilé (Comunidad Mhuysqa de Sesquilé, 2012; Santos y Mejía, 2010; Santos, Mejía y Candil, 2012). Y quienes transitaron por Cota y llegaron a Ráquira, para conformar una comunidad de seguidores que integraron ceremonias de los kággaba con un renovado pensamiento muisca, dieron comienzo a las primeras iniciaciones y entregas de dos herramientas muy sagradas y representativas de los mamos serranos y sus esposas: el poporo y el tejido. Por esa razón, las comunidades oficiales de Sesquilé y Cota, además de la comunidad alternativa de Ráquira, se consolidaron como epicentros de la red espiritual muisca con base en las cosmovisiones que compartían con el sistema de pensamiento 
de la Sierra Nevada de Santa Marta, cuyos líderes constituyeron una red de poporeros.

Según la versión general que manejan los chyquys de PNMC, los mamos llegaron a Bogotá y sintieron que la conexión energética la habían sentido con ellos, y no con las parcialidades oficiales, ya que estas en ese momento no contaban con autoridades importantes en los planos medicinal y religioso. Esta versión corresponde a la lectura que usualmente hacían los líderes de PNMC sobre los cabildos oficiales; los veían como simples "Juntas de Acción Comunal" para asuntos indígenas sin ningún trabajo espiritual (Gómez Montañez, 2009). Se trataba, por supuesto, de una respuesta de Sigifredo ante las acusaciones que sobre su organización hacían las comunidades de Bosa y Suba, que hace unos años se consideraban carentes de sabedores y líderes en el plano medicinal. En el año 2009, tres mamos ika llegaron a Bogotá. Gabriel, quien en ese entonces pertenecía a PNMC, los encontró un día en la maloca del jardín botánico preguntando por los muiscas. Más adelante, cuando rompió lazos con PNMC, Gabriel capitalizó su relación con estos mamos para conectarlos con los cabildos oficiales y, a la vez, para legitimar su papel en la red espiritual muisca. Con la participación de los tres mamos en los círculos de palabra de la maloca dirigidos por Sigifredo, se creó una alianza, y con esta un trabajo colaborativo que se concretó en procesos de resignificación de lugares sagrados en Bogotá. Tal alianza se dio en el marco de un proyecto que PNMC gestionó con el DAMA y de otro con la Alcaldía Local de Usaquén sobre rutas etnoturísticas. El mamo Libardo ${ }^{82}$, quien comandaba el trío de mamos, conoció algunos lugares referenciados por Sigifredo como de pagamento y devolvió algunas herramientas sagradas a los muiscas.

En una ceremonia llevada a cabo en un chunzuá del cerro La Conejera, en Suba, donde PNMC solía realizar círculos de palabra exclusivos de su comunidad, el mamo Libardo y sus hermanos devolvieron el fuego, ritual que consistía en entregar una herramienta de madera que se emplea en la Sierra Nevada de Santa Marta para friccionar

82 Su nombre ha sido cambiado. 
y así producir candela. Se entonaban los cánticos a Goranchanacha, cacique mitológico muisca, que simboliza el espíritu guerrero: Gorancha Goranchancha, ata guecha ye mbuyqa ('primer guerrero del camino de la gente'). A Libardo lo motivaba tanto conocer la mitología muisca que cuando notaba alguna incoherencia en las versiones y discursos de los líderes de PNMC, se molestaba. Una vez concluido el momento festivo de la ceremonia de entrega del fuego, y mientras los mamos conversaban con algunos alrededor de la fogata, Pedro, quien en ese entonces pertenecía a PNMC, le comentó a Libardo que él sabía de la existencia de seres que habitaban el sol. A Libardo le pareció que ese comentario de Pedro era "muy gnóstico" y se molestó. Los mayores de PNMC se reunieron para "llamar al orden" a Pedro y así evitar que las relaciones con el mamo se afectaran. Por este motivo, Pedro fue sancionado con la inhabilidad para asistir a círculos de palabra durante un tiempo. No le gustó esa decisión, que interpretó como muestra de arrogancia, y desde entonces se separó de PNMC.

Los trabajos entre mamos y líderes de PNMC continuaron, y como parte de las herramientas devueltas, el mamo Manuel, hermano de Libardo, comenzó a enseñarles a varias personas a tejer, hombres y mujeres. Esta práctica es, de acuerdo a las costumbres y los usos serranos, el complemento femenino del poporo. Por eso, mientras el mamo poporea, su esposa teje. La enseñanza de tal práctica precisamente activó la fuerza del don, que en este caso desplegó su poder por celos. Como el mamo Manuel permanecía en las casas de varios miembros de PNMC y allí realizaba consultas espirituales personalmente, algunos empezaron a identificarse más con las ideas del mamo y con su autoridad que con las de los propios chyquys de PNMC. De manera que la repartición del tejido por parte de los líderes de PNMC se hizo de manera descontrolada. Manuel terminó devolviéndose a la Sierra Nevada al enterarse que su esposa e hijos estaban enfermos. Sigifredo siempre afirmó que Manuel "se puso a traer tejido y la Madre se lo cobró". Para él, la enfermedad de la familia de Manuel era fruto de las fuerzas activadas por el don, el cual, según su versión, fue repartido de manera irresponsable. Tres meses después de la llegada de estos mamos a Bogotá, varios integrantes de la comunidad muisca habían aprendido a tejer sus conas (mochilas) mediante la técnica arhuaca. 
Los conflictos por la representatividad y la autoridad entre Sigifredo y los mamos se acrecentaron. Debido a esto, los mamos comenzaron a transformar y adaptar los preceptos elaborados sobre las narrativas del "despertar muisca" y la devolución de dones.

Como la metáfora que abarca la idea de la reetnicidad muisca es la del "despertar", los líderes de los cabildos oficiales consideran que actualmente no hay "abuelos muiscas" y que más bien su pueblo se compara con un "niño en proceso de guianza y aprendizaje". Para PNMC, por el contrario, sus autoridades tienen claro su linaje espiritual, de ahí que se consideren los legítimos guardianes del territorio y del conocimiento muiscas. Rodrigo, Xieguasinza, en uno de los círculos de palabra en el Templo del Sol llegó a decirles a los mamos que los muiscas "no eran ningunos hermanitos menores", aludiendo a la manera como los indígenas serranos se refieren a quienes no son de su territorio. Sigifredo comenzó a afirmar que el hecho de que los mamos devolvieran lo que, según él, "fue dado primero por los muiscas”, no significaba que "fueran sus abuelos". Para él, la tarea de los mamos era ayudar en una primera instancia al "despertar" y "dejar tranquilos" a los muiscas. Esta actitud nuevamente alimentó los juicios en su contra que lo tachaban de arrogante; líderes de comunidades oficiales la tomaron como una falta de respeto hacia los "abuelos mayores" y un atentado a los compromisos y las obligaciones que lleva consigo la entrega de dones. Este también fue uno de los motivos que generaron más diferencias entre Sigifredo y Gabriel, quien también por esto optó por irse de PNMC. Sin embargo, en varias ocasiones escuché decir a los propios mamos que su propósito no era imponer sus ideas a los muiscas, sino contribuir y acompañar su proceso de recomposición cultural. Manuel Socha, líder de medicina de la comunidad de Chía, en un círculo de palabra en Bosa, afirmó que los muiscas estaban "endeudándose cada vez más con la Madre". Además les escuché decir a varios poporeros que las herramientas devueltas "al final, eran prestadas" y que les correspondía a los mismos muiscas encontrar su propia medicina.

Pero sin duda el don que más controversias ha causado entre los muiscas y que fue el motivo principal de resolución de conflictos 
en el marco de las celebraciones en el Templo del Sol, es el poporo ${ }^{83}$. Por cierto, es importante anotar que el acto de poporear es equivalente al de mambear, solo que al estilo serrano. Poporear es un ejercicio considerado de gran valor espiritual, y dentro de las comunidades serranas está destinado solo para hombres de importantes linajes en el campo medicinal y religioso. A nivel general, el poporo se define como una "esposa espiritual", tal correspondencia alude tanto a la feminización del dios supremo en la figura de la Gran Madre - figura transversal en el campo de la reetnicidad actual panindianista- con quien se comulga y a quien se consulta, como a la relevancia del hecho de que el poporero tenga su mujer y trabaje con ella su medicina. La comunión profunda entre ambos simboliza, por supuesto, el acto sexual creador y sanador y es la que revela uno de los epicentros más conflictivos de estas redes.

Según uno de los líderes de PNMC, la entrega de poporos posicionó más el papel del manejo de la sexualidad en la medicina muisca. Incluso me comentó que uno de los mamos "buscaba mujeres" muiscas para tener relaciones sexuales con ellas y que por ello había sido expulsado de su comunidad en la Sierra Nevada de Santa Marta. Otro dio una versión diferente, decía que tal mamo se opuso a otros mayores de su territorio que buscaban "meterse con las mujeres" de iniciados jóvenes, que pactó con su comunidad la venida a Bogotá para trabajar espiritualmente con los muiscas y que formó parte de los mayores acogidos por el taita Orlando Gaitán, mediante quien se consolidó como uno de los mamos más representativos del proceso de recomposición cultural muisca en Bosa. Las cadenas de rumores sobre cuestionados actos y conductas relacionados con la relación entre líderes espirituales y mujeres conformaron los mapas de máxima inconmensurabilidad. $\mathrm{Al}$ entrevistar a diferentes líderes, encontré que una práctica común para deslegitimar la autoridad de otro o cuestionarlo moralmente era difundir rumores no confirmados de abuso sexual. Por lo general, estos testimonios comenzaban con la expresión "a mí me contaron, no sé...". Algunos abuelos son cuestionados por tener como "compañeras"

83 Véase la nota a pie n. ${ }^{\circ} 51$. 
mujeres menores que ellos, y algunos líderes de organizaciones que solía encontrarme en reuniones y escenarios de la red espiritual también fueron salpicados de rumores; se decía que "usaban su medicina para aprovecharse de las mujeres”. Una de mis estudiantes me comentó una vez que cuando le dijo a un joven muisca de la comunidad con la que realizaba su tesis de grado que le gustaría tomar yagé, él le dijo sin tapujos que cuando ella quisiera él le recomendaría con quién hacerlo, para "evitar que se metieran con ella". Al parecer, el joven muisca desconfiaba de ciertos personajes que solían brindar yagé a las comunidades. De otro lado, un mamo acusó gravemente a una de las comunidades muiscas de tener entre sus miembros "angelitos de pipí”. Los rumores y las confesiones que surgieron en varios escenarios de encuentro de esta comunidad desataron una transmisión de cadenas de información que alimentaron todavía más el conflicto moral y la inconmensurabilidad. Fue entonces cuando algunos decidieron "revisar el desorden” y averiguar cómo habían sido entregados varios poporos.

\section{El desorden del todo: deslegitimaciones}

Los mamos serranos que acompañaron la celebración en el Templo del Sol, en el 2010, formaban parte de un numeroso grupo que participó como equipo colaborativo de investigación en un proyecto liderado por el Iepri (Instituto de Estudios Políticos y de Relaciones Internacionales) de la Universidad Nacional de Colombia, en cabeza del profesor Reinaldo Barbosa. El proyecto que fue publicado (Barbosa, 2011) consistió en comprender los sistemas de pensamiento desde los cuales los pueblos originarios de la Sierra Nevada de Santa Marta explican su comprensión del territorio sagrado, los contenidos de la Ley Sé o ley de origen y la manera como regulan internamente sus relaciones interétnicas y la relación con sus territorios, para ellos mejor conocido como Ley Orgánica del Territorio (pp. 23-24). Uno de sus objetivos era:

Apoyar y acompañar encuentros de mamos, mamas y autoridades tradicionales de Gonawindwa-Shwndwa y de estos con ancianos sabios de otros pueblos originarios, encaminados a articular el 
proceso de consolidación territorial, gobernabilidad y “orden del todo" o justicia propia que se pretende, enmarcando dicho proceso dentro de una dinámica nacional de legitimación y reconocimiento de la sabiduría ancestral, en cuanto conocimiento y prácticas culturales auténticamente válidas jurídica, social y culturalmente respecto a los procesos internos de reapropiación y protección del territorio ancestral. (Barbosa, 2011, p. 25)

Rodrigo, Xieguazinsa, fue invitado a participar en el equipo de autoridades de otros pueblos originarios en el marco de este proyecto. La cercanía que así Rodrigo logró tener con el mamo Libardo le permitió transitar por los caminos que fueron interrumpidos para PNMC cuando los conflictos entre esta organización y los mamos y otras comunidades se agudizaron. Rodrigo recuerda esta época como una "gran desbandada" de personas que desertaron de PNMC, dejando así inacabado el proceso de entrega de poporos y conocimientos por parte del mamo Libardo. También fue un momento en el que Rodrigo capitalizó su relación con líderes u’wa para tratar de posicionar mejor el proceso de PNMC. Además, marcó el comienzo de los distanciamientos y las diferencias con el taita Orlando Gaitán, con quien se disputaría el liderazgo del Templo del Sol de Sogamoso.

Entonces me dicen que acompañara al anciano, que estaban recogiendo las autoridades de esos pueblos base, y como yo estaba en Boyacá entonces que me invitaban a ser parte de este equipo o consejo de mamos. Entonces este proceso se convierte como en un proceso ordenador, por eso, tituló la obra el maestro Reynaldo El orden del todo. Entonces el día 26 noviembre estuve en Guicán, y yo acompañé, y los relacioné a ellos, pues a mí me conocen allá. Se levantó una acta con los estudiantes de la Nacional que acompañaban al profe, se habló de Pueblo Nación, de la unión con los u'wa y todo esto de lo que se venía haciendo y ahí mismo me entregan un oficio donde me incluyen en el consejo provisional de mamos por los muisca. Me metieron por parte de los muisca y también a Lizarazo Chiratá, y a jate Ignacio y a Daza, somos los únicos cuatro muisca que aparecemos ahí. No sé por qué metieron a esta gente. El hecho es que después de ahí nos bajamos para 
Cumbal Chiles y hasta ahí todo bien con el taita. Entonces yo no entiendo por qué después ya voltearon la torta este año porque uno de los temas que salió de discusión era el tema del poporo. (Rodrigo Niño Rocha, 18 de diciembre del 2011)

Lo primero que había que ordenar era el verdadero origen del poporo. Luego había que revisar cómo fueron realizadas las entregas de los poporos a los muiscas: quién entregó a quién y de qué forma y con qué palabra. Así se configuró otra red espiritual que legitimó el liderazgo de algunos mamos e invalidó el de otros. A su vez, el abuelo Fernando Castillo, de la comunidad de Cota, quedó nombrado como el mayor de los muiscas, tal como me lo había confirmado Gabriel en nuestra charla virtual. Rodrigo lo cuenta.

Cuando algunas personas de la Sierra dicen que aquí [en el centro de Colombia] está su primer poporo, que se fue de aquí pa'llá. Y otros dicen allá "no es cierto, eso se vino de allá para acá". Y más que todo esas cosmogonías y bueno, "cómo vamos a hacer todo este ordenamiento con esos poporos”, entonces ahí es donde entra el abuelo Fernando y los tres o cuatro encuentros que ha hecho el taita hoy este año con la Sierra. Y entonces hay que llevar los de Suba, los de Bosa, etc. A los de Cota, Sesquilé, Chía, y los unió a ese trabajo. (Rodrigo Niño Rocha, 18 de diciembre del 2011)

Este era el proceder del taita, según Rodrigo, para mediar los conflictos: propiciar redes y encuentros para constituir y consolidar líderes y discursos que fueran configurando un sistema jerárquico y un ethos imperante. El desconocimiento del proceso de entrega de poporos a líderes de PNMC mostraba cada vez más que la representatividad y la autoridad de los abuelos muiscas coincidían con el oficialismo y la validez jurídica de sus cabildos. Rodrigo me contó que una vez Gabriel, en un encuentro de la Fundación Carare en el lago de Tota, llegó con líderes de Bosa que habían viajado con él a la Sierra a encontrarse directamente con los mamos mayores y había dicho públicamente que los "únicos poporos válidos" eran los que tuvieran los miembros de las comunidades de Bosa, Chía, Cota, Sesquilé y Ráquira. Cuando en una conversación le pregunté a Gabriel cómo interpretaba la entrega 
de su poporo estando en PNMC, me contestó que había "validado su proceso" mediante el trabajo realizado con los mamos desde su participación en Bosa y la Fundación Carare.

Entre los mamos que estaban en el Templo del Sol, en el 2010, se encontraba el mamo Alejandro ${ }^{84}$. Según Rodrigo, había llegado a un acuerdo con el mamo Libardo; la idea era que Alejandro hiciera la segunda parte de la entrega de poporos a PNMC, pues era quien manejaba un importante calendario, que, según las narrativas que se complementaban respecto a las relaciones históricas y espirituales entre la Sierra Nevada de Santa Marta y el territorio muisca, era una información muy relevante para ser devuelta. De otro lado, que los mayores le hubieran confirmado a Rodrigo, en uno de sus viajes a la Sierra Nevada, su papel de mamo, es un anclaje con el que legitima su participación en la devolución de dones. Adicional a esto, Rodrigo amplifica la imagen e importancia del mamo Alejandro; el nivel de inconmensurabilidad del conflicto étnico creció al saber que el mamo Alejandro comenzó a dar la palabra sobre la sexualidad que el poporo implica.

Entonces el anciano [Alejandro] estaba afanado de entregar esos matrimonios de poporo y de huso. En uno de los diálogos el taita [Orlando Gaitán] me dijo: "Mire, como los cabildos de Suba, Bosa, etc., no entienden esa vaina de los poporos, no es claro, y ustedes son los que han venido haciendo un trabajo juicioso con Libardo y con los otros mamos que han venido, yo les presto el terreno de La Vega para que hagan el trabajo, lo que se pretende es unificar y ponerle orden desde lo muisca". Entonces el trabajo con Libardo es un trabajo desde lo muisca, hubo cosas muy profundas, cuando yo fui a la Sierra yo fui a nombre de mi pueblo para pedir la aseguranza de Pueblo Nación Muisca Chibcha, allí se ofrecieron unos mamos donde me hicieron una consulta, me aclararon que yo era un mamo. Como él no entregó esa palabra y cómo tiene que ver con nosotros, los treinta y seis pueblos base, entonces lo asumimos como una sabiduría de los muisca también que estaba guardada por estos tayronas arhuacos. Porque en la Sierra solo hay

84 Seudónimo para este estudio. 
tres mamos que conocen ese calendario y uno de ellos es Alejandro. Tengo entendido en sus historias que nos cuenta, su abuelo ya había venido por aquí a estas tierras hasta Cumbal guardando esa tradición, entonces él traía esa tradición milenaria, y entonces lo aprovechan allá en Carare, pero cuando el anciano empezó a ser estricto, porque el taita delegó a dos carare para ese equipo de mamos. Ya después de haber ido a Cumbal Chiles y haber hecho pagamento en tales obras específicas, nos reunimos a evaluar y el anciano dice: "Bueno, vamos a hablar de la dietación”, y como eso tiene que ver con el tema sexual entonces los carare dijeron “no, yo esa vaina, yo no venía a eso, yo venía era a tomar fotos”. (Rodrigo Niño Rocha, 18 de diciembre del 2011)

Y se puede decir que la inconmensurabilidad se completó entre los mismos líderes foráneos que apoyaban la entrega de poporos y otros dones a los muiscas. Las divisiones y conflictos entre autoridades espirituales afectaba, según Rodrigo, las mismas relaciones conflictivas entre los muiscas. El mamo Alejandro, quien en el Zocam del 2010 fue apoyado por el taita Orlando Gaitán y su fundación, luego sería retado, confrontado y deslegitimado como autoridad espiritual. Esta inversión de su papel se interpreta como súbita, considerando que en la comparsa - anteriormente descrita-, cuando el ritmo de caminata me hizo permanecer al lado del mamo, una miembro de la Fundación Carare se acercó para alejarlo de mí, como si quisiera proteger a alguien muy importante de tan perversa presencia. Algo curioso de aquel episodio fue que el mamo Alejandro me sonreía constantemente mientras lo separaban, caminaba lento por andar enfermo de una pierna. A la mirada inquisitiva de esta persona, la cual nunca entendí, se sumó un acto sumamente agresivo por parte de otro miembro de la fundación, que tocaba un tambor. Cuando vio que su compañera distanciaba al mamo de mí, se acercó y con su codo me obligó a separarme aún más. Lejos de mi molestia y de lo contradictorio que fue ver a este tamborilero corpulento tratando de brindar una medicina al final de la limpia en el templo — que no acepté, por cierto—- la acción de estas dos personas parecía una demostración del grado de sacralidad que el mamo representaba para ellos. Pero dicha sacralidad devino en completa 
profanación cuando el mamo en una ocasión intentó interpretar la medicina del yagé, comparándola con la del poporo en lo que a la sanación de los territorios se refiere. Rodrigo fue testigo de tal confrontación simbólica entre autoridades espirituales de alta jerarquía.

Entonces a mí se me hace extraño que de la noche a la mañana el taita diga "no, el anciano Alejandro no es". Ahí hay un tema, y es que en las reuniones que se hacían en La Vega, el anciano [Alejandro] me daba mucha queja, se quejaba mucho de Libardo y del taita [Orlando Gaitán] porque no hacían el trabajo que él pensaba que debía hacerse. Entonces yo un poco angustiado convoqué a un consejo en La Vega en la mañana un domingo, cosa que le disgustó al taita, y entonces estaba Reynaldo y los dos carare, Juan, el abuelo Víctor, el taita, estaba Xieguazinsa, habíamos como unos ocho, Gabriel no estaba. Entonces ahí se habló y yo los eché a todos al agua. Dije: "Bueno, yo los convoqué porque tenemos mucha preocupación, el anciano anda es con las estrellas y va aprisa, nosotros no le entendemos y él siempre se anda quejando aquí del taita, de Lorenzo, de todos, entonces yo quiero que aclaremos eso porque nos queda difícil seguir trabajando así con el anciano. Yo quiero que nos aclaren aquí cuál es la diferencia que existe entre Lorenzo y el mamo, porque él se queja que Lorenzo no asiste a los trabajos que tiene que hacer". "No, nosotros no tenemos ningún problema, algunas diferencias por el calendario porque en mi linaje lo vemos de otra manera y el anciano lo ve de otra manera, pero no hay problema, nosotros seguimos haciendo el trabajo, apoyamos el proceso". [Rodrigo continúa] "Y los carare, pues el anciano se queja de que ninguno está haciendo el trabajo con él, entonces el ordenamiento y el movimiento de las estrellas, y con respecto al taita, él también se queja, entonces yo quiero pues que haya como claridad en todo eso". El taita se emberracó fue por eso. Entonces dijo: "No, yo sí dejé claro al anciano, y dejó claro aquí en este consejo que yo soy de yagé, de mambe y ambil. Yo no soy de poporo. Yo ahí no me meto". Entonces el anciano dijo algo muy fuerte: "Yo lo que he entendido es que yagé sí cura persona, pero no cura territorio, a la Madre”. Uhhh, eso 
le ofendió al taita. Y entonces lo último que venía diciéndose es que el anciano no era legítimo, que la Sierra no lo reconocía, deslegitimando todo lo nuestro a partir del anciano. En la Sierra hay un problema tremendo, eso no se sabe quién es quién. (Rodrigo Niño Rocha, 18 de diciembre del 2011)

Cuando un sabedor transmite sus conocimientos a sus iniciados, forma un linaje. Cuando el sabedor es invalidado, todo su linaje se invalida. Esa es la ecuación mediante la cual Rodrigo interpretaba las afectaciones que los conflictos por autoridad y representatividad entre líderes foráneos causaban a PNMC. Alejandro fue completamente invalidado como autoridad y parte de la gran red del "orden del todo" cuando en una consulta que los mamos hacían de un territorio visitado, comenzó a tener visiones de seres malignos. Al parecer, su lectura no coincidía con la de otros mamos presentes, quienes también empleaban métodos serranos de adivinación como el yatukua (adivinación con agua), que permite a los especialistas tener contacto directo con la Madre Tierra y los ordenamientos de su tejido territorial y ecosistémico (Cárdenas, 2002b). Esto me lo contó el mismo profesor Reynaldo Barbosa, autor del libro derivado del proyecto. Estas consultas directas con la Madre Tierra por parte de los mamos son ejemplos de memoria mística ${ }^{85}$. Aunque en principio esta memoria se diferencia de la dogmática de acuerdo con Halbwachs (2004), el privilegio de tener acceso directo a los dioses configura sus propios dogmatismos, jerarquías y poderes. Los séquitos, a su vez, legitiman el poder de sus maestros y reproducen esas mismas contiendas y jerarquías. En una reunión en Bosa, en el marco de un proyecto que buscó resignificar lugares sagrados de Bogotá, uno de los líderes y poporeros de esa comunidad, Edward Arévalo Neuta, pronunció vehementemente que "quien se uniera al proyecto de la resignificación, tenía que unirse a la línea del jade Ramón”. Este jade (o mamo de mamos) era el "mayor" para la comunidad de Bosa. Con este tipo de afirmaciones, se configuran ideologías y facciones entre las redes étnicas. Carlos Candil, de la comunidad de Sesquilé, por su parte,

85 Noción explicada en el apartado "Memorias mística y dogmática" del tercer capítulo. 
un día me comentó que el problema de la resignificación era precisamente que cada comunidad seguía "la palabra" de un mamo específico y que eso complicaba llegar a acuerdos. El mismo joven que previno a mi estudiante de las tomas de yagé, en otra ocasión dijo sin tapujos que los poporeros "eran un gueto", refiriéndose al carácter cerrado y exclusivo de la membresía a sus grupos.

El poder y la legitimidad que había adquirido el taita Orlando Gaitán y su fundación, sumados a la molestia que le causó a Margarita Silva, directora del Museo Arqueológico de Sogamoso, el uso indebido del Templo del Sol por parte de los muiscas en el 2010, dejaron a Rodrigo prácticamente excluido de las actividades que la institución coordinó para la Fiesta del Zocam del 2011. Los congresos muiscas para debatir y aclarar el tema de los poporos y los asuntos respecto a PNMC nunca se llevaron a término. El taita tuvo problemas con Margarita, y en el 2012, la Fundación Carare no formó parte de la celebración. El museo no prestó el templo para recibir el sol del solsticio en la madrugada del 21 de diciembre de ese año, como era ya una costumbre. La celebración del Zocam para los muiscas se limitó a un pequeño círculo de palabra alrededor de una fogata en el parque Concuchua, aledaño al museo y al templo. Rodrigo lideró la palabra, mientras tímidamente se integraban líderes de medicina de Chía, Sesquilé y Cota. Hubo cánticos y se repartió medicina de tabaco y chicha. A diferencia de años anteriores, no hubo grandes reuniones para debatir sobre el sentido del poporo. Al final, el taita Orlando Gaitán no logró quedarse con el liderazgo de las ceremonias del Templo del Sol, y Rodrigo, sin volver a ser invitado por el dueño de la casa, continuó su empresa como el andariego y solitario que siempre ha sido.

\section{Sumario: conflictos estructurantes del "despertar muisca"}

El auge de la maloca del Jardín Botánico de Bogotá materializaba las narrativas sobre el pasado remoto en las que los pueblos hermanos se comprometieron a devolver a los muiscas sus dones. En este caso, el abuelo Víctor Martínez Taicoma "devolvió" la palabra de mambe y ambil y la maloca contuvo su fuerza sanadora. Sigifredo elaboró 
un anclaje mediante la emergencia de su alter ego, Suaga Gua, y se vinculó a esta narrativa, otorgándose un papel fundamental de autoridad espiritual y legítimo receptor de la palabra del Amazonas. Los conflictos que esto generó con las comunidades oficiales avivaron las viejas disputas y los juicios que existieron cuando Sigifredo transitó por sus papeles de gestor cultural, asesor y autoridad indígena.

Asimismo, los discursos, las metodologías y las jerarquías creados en la maloca y otros espacios medicinales y de círculos de palabra tejieron un campo de percepciones e identificaciones en los que varios líderes desplegaron sus ethos para juzgar las acciones de sus homólogos y excluirlos de diferentes escenarios. Esos mismos discursos, metodologías y jerarquías propusieron ideales y valores de ser muiscas basados en lo que se consideraba que era su esencialidad. Fue así como se postuló en estas redes la idea de que "ser muisca era ser espiritual" y que esto solo podía fundamentarse en lo que los muiscas denominan "la memoria ancestral”. Este fundamentalismo, lejos de ser un romántico postulado, configuró nuevos criterios de inclusión y exclusión. Las lecturas sobre la arrogancia, la deslealtad y el irrespeto de los llamados “abuelos ancestrales" parecían ser la base del veneno que conllevaba la devolución de dones por parte del taita Víctor Martínez Taicoma y de los mamos de la Sierra Nevada de Santa Marta.

Los juicios y las exclusiones de las que PNMC ha sido objeto en el plano de las relaciones de poder espiritual y medicinal han trascendido al plano político. Esta organización no fue invitada a participar en las mesas de trabajo que buscan crear una consulta previa exclusiva para que la política pública indígena encuentre asidero en el Plan de Desarrollo de Bogotá. Sin embargo, el reconocimiento social, político y espiritual de los chyquys en relación con los demás líderes sigue presentando variaciones de acuerdo a los contextos y las situaciones, en consecuencia, algunas facciones continúan elaborando transacciones que superan el esquema tradicional conformado por partes definidas del conflicto. Cabe nombrar, como ejemplo, que varios integrantes de cabildos oficiales, al sentir que su comunidad no trabaja seriamente el tema espiritual, han optado por solicitar ser miembros de PNMC o reconocer a Sigifredo como su abuelo, lo que refuerza aún más el principio histórico-transaccional. 
Gracias al desarrollo de los círculos de palabra en la maloca del jardín botánico, las enseñanzas del taita Víctor y de Sigifredo, Suaga Gua, posibilitaron un proceso constante de producción, circulación y recepción de ideas y discursos que se replicaron en otros escenarios, creando así un mercado de lenguaje espiritual muisca. Por un lado, los miembros de la red étnica proponen reglas e imperativos éticos y morales que se han empezado a consolidar como un cuerpo de valores coherente para definir un renovado estilo de vida indígena muisca. Por otro, estos principios a veces parecen configurar ethos derivados y acomodados según las circunstancias y los puntos de vista de sus seguidores y practicantes, hasta tal punto que son incongruentes; se pueden identificar contradicciones en su aplicación cuando se revisan los esquemas de percepción, pensamiento y acción de varios de sus practicantes.

Con la agencia del abuelo Víctor, el mambe y el ambil se convirtieron en las primeras herramientas espirituales que los pueblos hermanos comenzaron a devolver a los muiscas, según cuentan la mayoría de sus practicantes. Explicaba en el capítulo anterior que este tipo de herramientas, incluido el yagé en cuanto planta medicinal inspiradora, configuraron redes de iniciadores e iniciados y con ello linajes y lealtades. A los círculos de palabra fueron asistiendo cada vez más personas que portaban en sus mochilas varias medicinas. $\mathrm{Y}$ a medida que fueron legitimándose las autoridades de taitas y mamos, los grupos como PNMC se fraccionaron, lo que dio lugar a que emergieran nuevas facciones y redes de intercambio. Cada integrante transitó por diversas etapas de la historia de los múltiples conflictos entre comunidades y organizaciones y buscó anclarse a la gran narrativa del "despertar" que vinculaba su presente con los pasados y las memorias imaginativas y simbólicas de larga data.

La llegada de mamos serranos a territorio muisca y su participación en diferentes espacios de colaboración e intercambio con sus líderes complementó la red étnica de lo medicinal-espiritual y aportó nuevas devoluciones y circulaciones de dones. El poporo se convirtió en una de las principales herramientas iniciadoras y en un relevante objeto de disputas por la legitimidad de las autoridades, la validez de sus procesos y la ética de sus procederes. De esta manera, la obligación 
implícita en la lógica del intercambio de dones hizo que estos desplegaran sus fuerzas tanto curativas como confrontadoras y generadoras de enfermedad y malestar. Al mismo tiempo, los discursos, las enseñanzas y las prácticas medicinales que se difundieron por parte de taitas y mamos contribuyeron a la formación de métodos de armonizar las relaciones entre las personas, los espíritus, sus yo internos, sus grupos y abuelos. Marcaron jerarquías, linajes y cadenas de lealtad, además conflictos por la representatividad y el poder simbólico entre líderes indígenas como legítimos dadores y receptores de dones medicinales.

$\mathrm{Al}$ recomponer un mapa general de la historia social de las disputas, la relación entre la memoria y el conflicto la he elaborado con base en los poderes simbólicos que operan en la construcción de los mundos sociales de quienes participan de la red étnica del "despertar muisca”. La memoria compone parte de dicha dimensión simbólica del conflicto mediante la construcción de una narrativa de larga data que encuentra coherencias morales con el presente a través de la reproducción de intercambios y transacciones entre muiscas, taitas y mamos que se apoyan en dicha historicidad. El carácter cambiante y mutante de la historia también hace de los conflictos procesos intratables cuyas causas se sustituyen y renuevan. A eso he denominado el "principio histórico-transaccional" del conflicto étnico. De igual forma, se componen memorias a partir de la manera como algunos de los integrantes de la red se narran a sí mismos y se vinculan moralmente al tejido conflictivo. A eso lo llamo "principio de anclaje". A medida que ambos principios son empleados por parte de cualquier integrante de la red, diferentes ethos se evidencian como esquemas de percepción, pensamiento y acción que hacen del campo etnopolítico muisca una arena de múltiples conflictos por la identidad y la memoria indígenas, en la que las escalas de inconmensurabilidad crecen y decrecen conforme se desarrolla la historicidad de los mismos conflictos y los tránsitos de sus partes y facciones. 